\title{
Groene Cirkels
}

\section{Een Bij-zonder kleurrijk landschap}

in het Land van Wijk en Wouden, Leidse Ommelanden en Duin- en Bollenstreek

\section{Handreiking 3.0 voor inrichting en beheer van groene} infrastructuur voor bestuivende insecten

Sabine van Rooij (redactie)

Wageningen Environmental Research

bijdragen van:

\section{Anouk Cormont}

Wageningen Environmental Research

Willemien Geertsema

Wageningen Universiteit,

Plantenwetenschappen,

Centre for Crop Systems Analysis

Arjen de Groot

Wageningen Environmental Research

Martijn Haag

Wageningen Environmental Research

\section{Paul Opdam}

Wageningen Environmental Research

\section{Menno Reemer}

EIS Kenniscentrum Insecten en andere ongewervelden, Naturalis Biodiversity Center

Robbert Snep

Wageningen Environmental Research

Joop Spijker

Wageningen Environmental Research

\section{Eveliene Steingröver}

Wageningen Environmental Research

Anthonie Stip

De Vlinderstichting

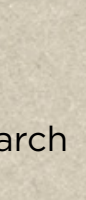

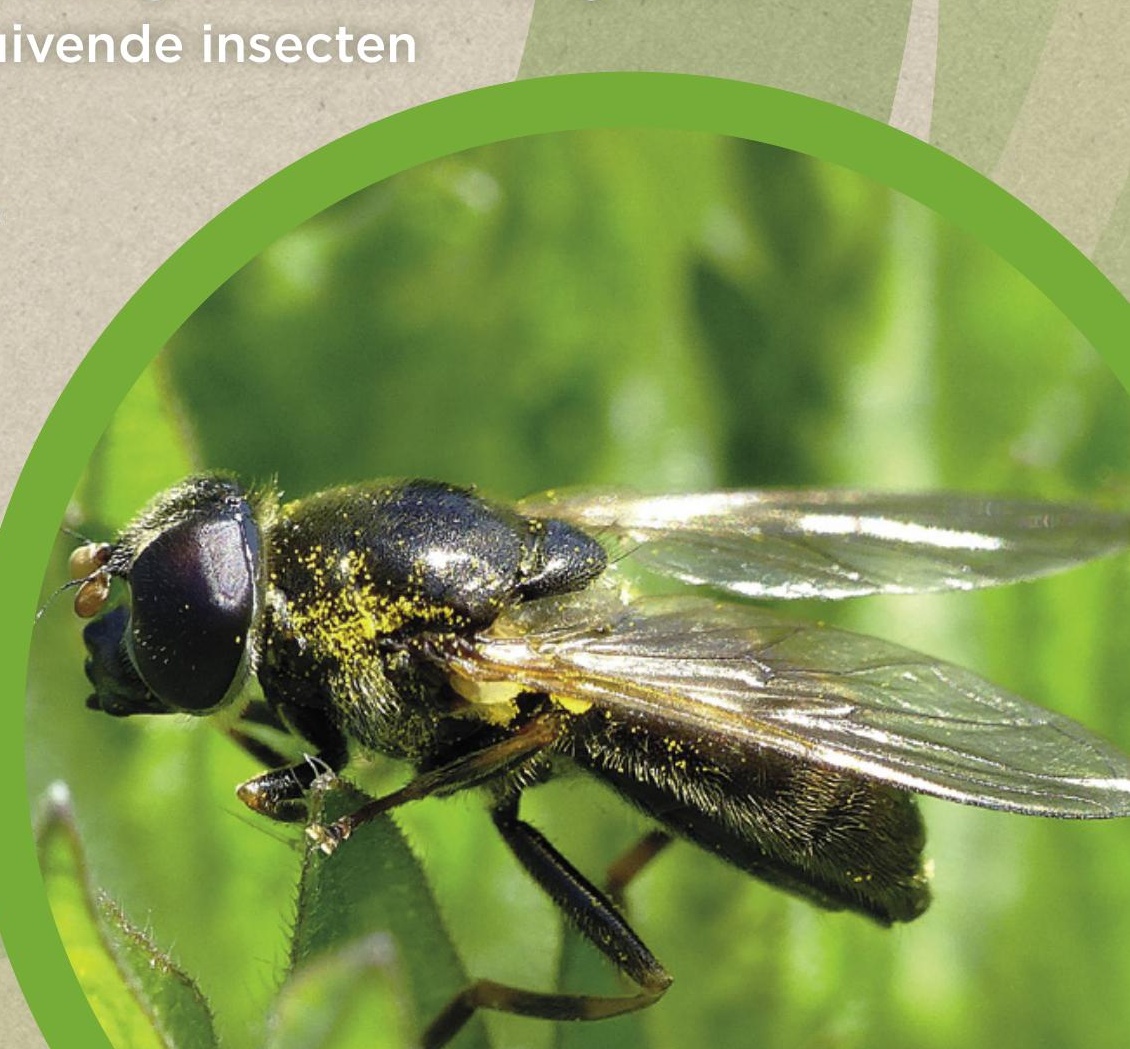

Wim Ozinga

Wageningen Environmental Research 


\section{Groene Cirkels}

Een schone, klimaatneutrale en klimaatbestendige HEINEKEN brouwerij in een klimaatneutrale keten, een duurzame economie, een aangename leefomgeving en kennis ontwikkelen voor een klimaatneutrale maatschappij. Dat zijn de ambities waarvoor Groene Cirkels zich inzet. Dat doet zij door de natuur als uitgangspunt te nemen en programma's te realiseren rond de onderwerpen energie, water, grondstoffen, mobiliteit en leefomgeving. Het initiatief Groene Cirkels, gevormd door multinational HEINEKEN, provincie Zuid-Holland, Hoogheemraadschap Rijnland en kennispartners Wageningen Environmental Sciences en Naturalis Biodiversity Center, wil graag de voor deze ambities benodigde partijen aan zich binden en een voorbeeld van wereldklasse zijn.

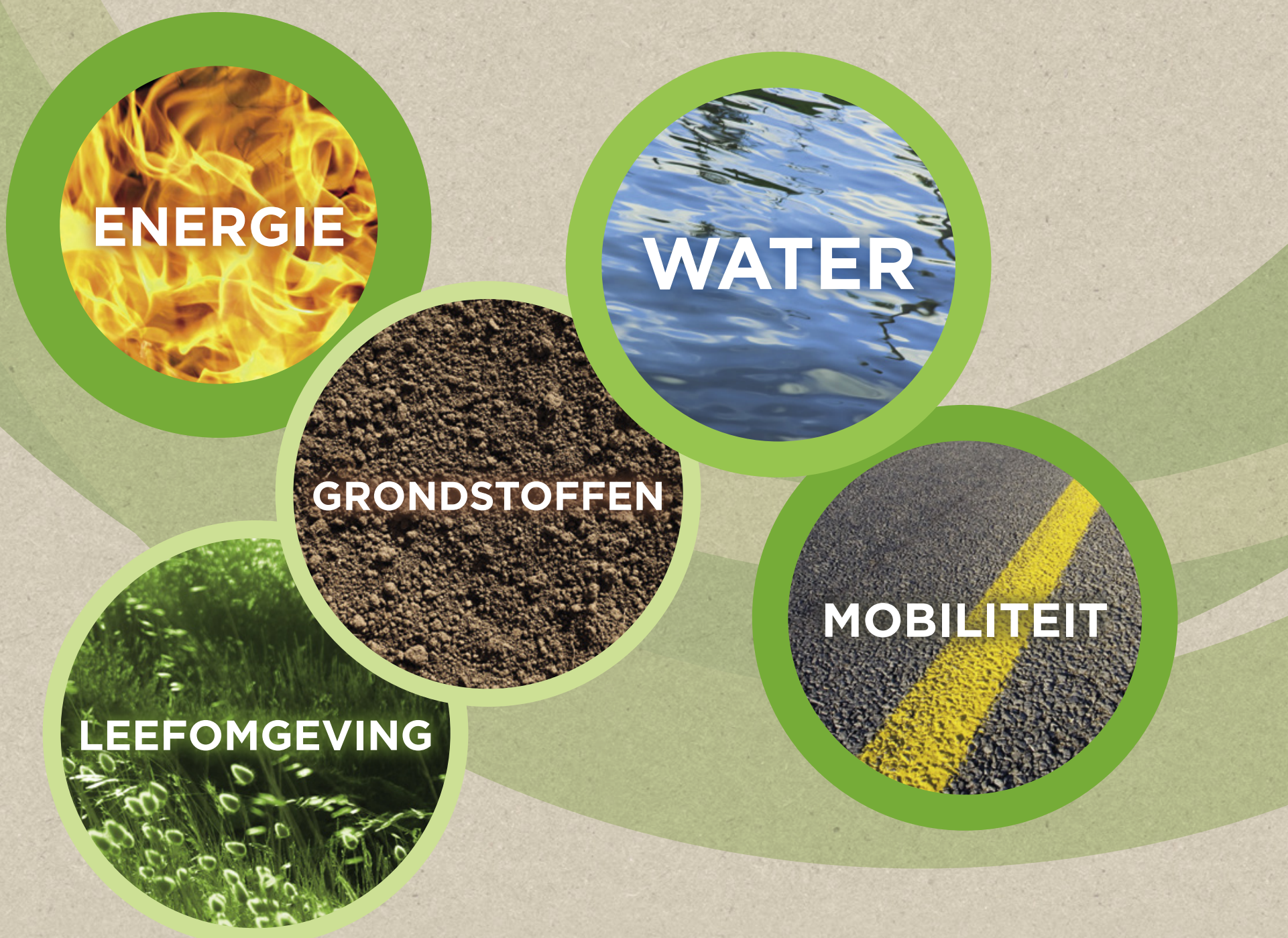




\section{Een Bij-zonder kleurrijk landschap in het Land van Wijk en Wouden, Leidse Ommelanden en Duin- en Bollenstreek}

Handreiking 3.0 voor inrichting en beheer van groene infrastructuur voor bestuivende insecten

Sabine van Rooij ${ }^{1}$ (redactie), bijdragen van Anouk Cormont ${ }^{1}$, Willemien Geertsema ${ }^{2}$, Arjen de Groot $^{1}$, Martijn Haag ${ }^{1}$, Paul Opdam ${ }^{1}$, Menno Reemer ${ }^{3}$, Robbert Snep ${ }^{1}$, Joop Spijker ${ }^{1}$, Eveliene Steingröver ${ }^{1}$, Anthonie Stip ${ }^{4}$ en Wim Ozinga ${ }^{1}$

\footnotetext{
1 Wageningen Environmental Research, Wageningen-UR

2 Wageningen Universiteit, Plantenwetenschappen, Centre for Crop Systems Analysis

3 EIS Kenniscentrum Insecten en andere ongewervelden, Naturalis Biodiversity Center

4 De Vlinderstichting
}

Dit onderzoek is uitgevoerd door Wageningen Environmental Research, in opdracht van en gefinancierd door het programma Groene Cirkels Bijenlandschap, onderdeel van Groene Cirkels, de samenwerking tussen Heineken, Provincie Zuid-Holland, Wageningen Environmental Research, Hoogheemraadschap van Rijnland en Naturalis Biodiversity Center.

Wageningen Environmental Research

Wageningen, maart 2020

Gereviewd door:

Anne Schmidt, senior onderzoeker (Wageningen Environmental Research)

Akkoord voor publicatie:

Judith Westerink, teamleider van Biodiversiteit \& Beleid

Groene Cirkels rapport 11

Rapport 2999

ISSN 1566-7197 
Sabine van Rooij ${ }^{1}$ (redactie), bijdragen van Anouk Cormont, Willemien Geertsema, Arjen de Groot, Martijn Haag, Paul Opdam, Menno Reemer, Robbert Snep, Joop Spijker, Eveliene Steingröver, Anthonie Stip en Wim Ozinga, 2020. Een Bij-zonder kleurrijk landschap in het Land van Wijk en Wouden, Leidse Ommelanden en Duin- en Bollenstreek; Handreiking 3.0 voor inrichting en beheer van groene infrastructuur voor bestuivende insecten. Wageningen, Wageningen Environmental Research, Rapport 2999. 48 blz.; 10 fig.; 5 tab.; 0 ref.

Dit rapport biedt actoren in het bijenlandschap Groene Cirkels handvaten voor het bij-vriendelijk maken van hun gebied. In het rapport worden ecoprofielen voor bestuivers en bouwstenen voor het bijenlandschap gepresenteerd en aanbevelingen gedaan voor een bij-vriendelijk beheer en inrichting van de groene infrastructuur. Het bijbehorende bijlagerapport geeft meer achtergrondinformatie over de ontwikkelde bouwstenen en de kennis waarop deze zijn gebaseerd.

This report provides actors in the bee landscape Green Circles directions for making their area atfriendly. The report introduces ecoprofiles for pollinators and building blocks for the bee landscape and makes recommendations for a bee friendly management and design of the green infrastructure. The accompanying annex report provides more background information on the building blocks developed and the knowledge on which they are based.

Trefwoorden: bestuivende insecten, wilde bijen, zweefvliegen, vlinders, ecologische netwerken, ecoprofielen

Dit rapport is gratis te downloaden van https://doi.org/10.18174/519243 of op www.wur.nl/environmental-research (ga naar 'Wageningen Environmental Research' in de grijze balk onderaan). Wageningen Environmental Research verstrekt geen gedrukte exemplaren van rapporten.

2020 Wageningen Environmental Research (instituut binnen de rechtspersoon Stichting Wageningen Research), Postbus 47, 6700 AA Wageningen, T 0317480700 , www.wur.nl/environmental-research. Wageningen Environmental Research is onderdeel van Wageningen University \& Research.

- Overname, verveelvoudiging of openbaarmaking van deze uitgave is toegestaan mits met duidelijke bronvermelding.

- Overname, verveelvoudiging of openbaarmaking is niet toegestaan voor commerciële doeleinden en/of geldelijk gewin.

- Overname, verveelvoudiging of openbaarmaking is niet toegestaan voor die gedeelten van deze uitgave waarvan duidelijk is dat de auteursrechten liggen bij derden en/of zijn voorbehouden.

Wageningen Environmental Research aanvaardt geen aansprakelijkheid voor eventuele schade voortvloeiend uit het gebruik van de resultaten van dit onderzoek of de toepassing van de adviezen.

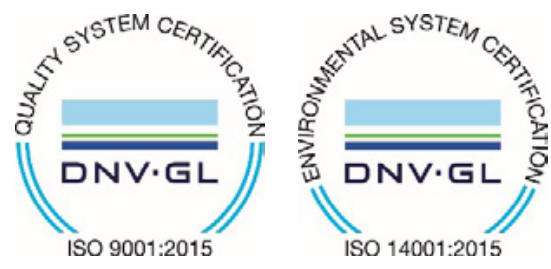

Wageningen Environmental Research werkt sinds 2003 met een ISO 9001 gecertificeerd kwaliteitsmanagementsysteem. In 2006 heeft Wageningen Environmental Research een milieuzorgsysteem geïmplementeerd, gecertificeerd volgens de norm ISO 14001.

Wageningen Environmental Research geeft via ISO 26000 invulling aan haar maatschappelijke verantwoordelijkheid.

Wageningen Environmental Research Rapport 2999 | ISSN 1566-7197

Foto omslag: Vrouwtje Kruiskruidgitje, Menno Reemer 


\section{Inhoud}

$\begin{array}{ll}\text { Verantwoording } & 5\end{array}$

Groene Cirkels Thema leefomgeving, project Bijenlandschap $\quad 7$

$\begin{array}{ll}\text { Inleiding } & 9\end{array}$

1.1 Waarom een bijenlandschap? $\quad 9$

$\begin{array}{ll}1.2 & \text { Voor wie is deze handreiking? }\end{array}$

1.3 Toelichting op de verschillende versies van de handreiking 11

1.4 Leeswijzer 11

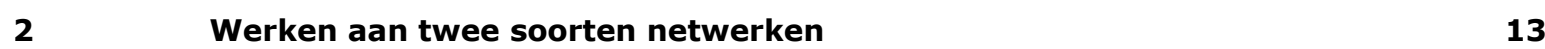

2.1 Het sociale netwerk: initiatieven in de regio 14

2.2 Het bijennetwerk $\quad 15$

2.2.1 Een duurzaam netwerk voor bestuivende insecten $\quad 15$

2.2.2 Duurzame productie van honing $\quad 22$

$\begin{array}{ll}2.2 .3 \text { Een 'beleefbaar' landschap } & 22\end{array}$

2.2.4 Potentie voor Bed \& Breakfast-gebieden $\quad 22$

$\begin{array}{lll}2.3 & \text { Contouren van het Bijennetwerk } & 28\end{array}$

$\begin{array}{lll}2.4 & \text { Bijkomende voordelen van het Bijennetwerk } & 28\end{array}$

$3 \quad$ Hoe maak ik mijn terrein bij-vriendelijk?

$\begin{array}{lll}3.1 & \text { Bij-vriendelijk beheer } & 31\end{array}$

$\begin{array}{lll}3.2 & \text { Bij-vriendelijke inrichting } & 34\end{array}$

$4 \quad$ Aandachtspunten voor specifieke terreintypen $\quad 38$

$\begin{array}{lll}4.1 & \text { Bedrijventerreinen } & 38\end{array}$

$\begin{array}{lll}4.2 & \text { Gemeentelijk groen } & 41\end{array}$

$\begin{array}{lll}4.3 & \text { Oevers en bermen } & 42\end{array}$

$\begin{array}{lll}4.4 & \text { Agrarisch gebied } & 45\end{array}$

$\begin{array}{ll}\text { Meer weten? } & 46\end{array}$

$\begin{array}{ll}\text { Woordenlijst } & 47\end{array}$ 


\section{Verantwoording}

Rapport: 2999

Projectnummer: 5200045521

Wageningen Environmental Research (WENR) hecht grote waarde aan de kwaliteit van zijn eindproducten. Een review van de rapporten op wetenschappelijke kwaliteit door een referent maakt standaard onderdeel uit van ons kwaliteitsbeleid.

Akkoord Referent die het rapport heeft beoordeeld,

functie: $\quad$ Senior Onderzoeker Vegetatie, Bos and Landschapsecologie

naam: Drs. Anne Schmidt

datum: 20 maart 2020

Akkoord teamleider voor de inhoud,

naam: Dr. Judith Westerink

datum: 20 maart 2020 


\section{Groene Cirkels}

\section{Thema leefomgeving, project Bijenlandschap}

Een klimaatneutrale HEINEKEN-brouwerij in een klimaatneutrale keten, een duurzame economie, een aangename leefomgeving en het ontwikkelen van kennis voor een klimaatneutrale maatschappij, dat zijn de ambities waarvoor Groene Cirkels zich inzet. Dat doet zij door de natuur als uitgangspunt te nemen en programma's te realiseren rond de onderwerpen energie, water, grondstoffen, mobiliteit en leefomgeving. Het initiatief Groene Cirkels, gevormd door multinational HEINEKEN, provincie ZuidHolland, Hoogheemraadschap Rijnland en kennispartners Wageningen Environmental Research en Naturalis Biodiversity Center, wil graag de voor deze ambities benodigde partijen aan zich binden en een voorbeeld van wereldklasse zijn.

Groene Cirkels wil met bedrijventerreinen, gemeentelijk groen, tuinen en wegbermen de bijen weer terugbrengen in het landschap.

Met het project Bijenlandschap wil Groene Cirkels meerwaarde creëren. De 'groene infrastructuur' die door het creëren van robuuste, bloemrijke leefgebieden, verbindende linten en 'stapstenen' ontstaat, heeft meerdere functies. Ecologische functies, maar ook bijvoorbeeld recreatieve functies. HEINEKEN Zoeterwoude kan door de omvang van het terrein (ca. 100 ha) en de gunstige ligging een belangrijk onderdeel worden van een robuust en divers bijenlandschap. Maar het bijenlandschap reikt ver buiten het terrein van de brouwerij.

Bij het ontwikkelen van kennis voor het trainingsmateriaal, waaronder dit rapport, een presentatie en bijbehorende brochure, heeft kennispartner Wageningen Environmental Research samengewerkt met het EIS Kenniscentrum Insecten en met De Vlinderstichting. Ook is er samengewerkt en afgestemd met Stichting Land van Wijk en Wouden, die in het Bijenlandschap een coördinerende rol vervult.

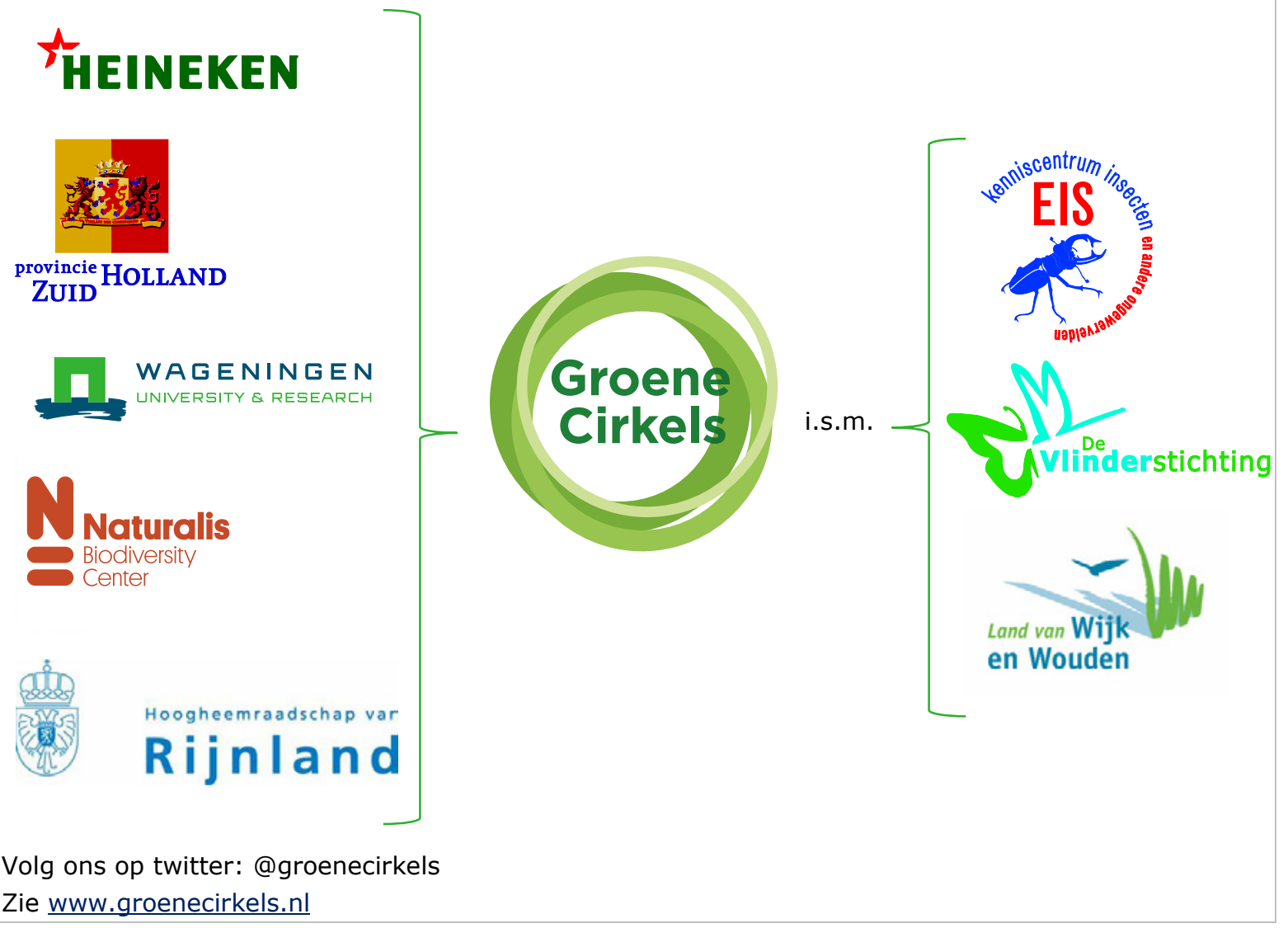




\section{$1 \quad$ Inleiding}

\subsection{Waarom een bijenlandschap?}

Het programma Groene Cirkels heeft het initiatief genomen tot het realiseren van een duurzaam bijenlandschap in het land van Wijk en Wouden. Met deze handreiking willen we een impuls geven aan het realiseren daarvan.

De ambitie: Samen met verschillende partijen werken aan een regionaal netwerk van bloemrijke plekken voor bestuivende insecten, dat ook honing oplevert en er mooi uitziet. Hiermee willen we de bestuiving van landbouwgewassen en van wilde planten in de regio voor de toekomst veilig stellen. Zo wordt samen met regionale partijen gewerkt aan de versterking van de natuurlijke hulpbronnen in de regio.

\section{Omdat het nodig is voor bestuiving, nu en in de toekomst}

Voor een goede en betrouwbare bestuiving is een hoge diversiteit aan bestuivende insecten belangrijk. In Nederland hebben we zo'n 350 verschillende wilde bestuivende insectensoorten. Door variatie in onder andere bloemvormen, kelkdiepte en bloeiseizoen zijn er gespecialiseerde insecten nodig, aangepast op bloeivorm en het bloeiseizoen. Ook moet bestuiving plaats kunnen vinden onder verschillende omstandigheden: bij goed en slecht weer, in vroege en late voorjaren. Nu eens doet de ene soort het goed, dan is er weer een andere die het meeste werk verzet. Diversiteit aan bijen waaronder ook hommels! -, zweefvliegen en vlinders geeft zekerheid voor bestuiving door de jaren heen. In Californische amandelboomgaarden kunnen bijvoorbeeld bij sterke wind honingbijen alleen onder in de boom hun werk doen, boven in de boom nemen meer windbestendige soorten de bestuiving voor hun rekening.

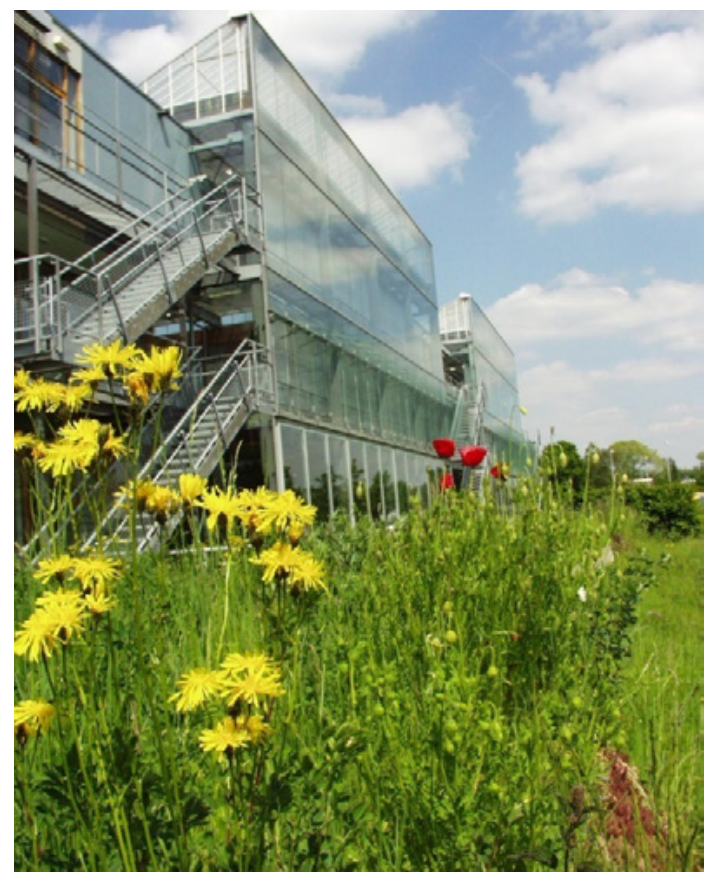

Een bloemrijke strook is ook aantrekkelijk voor mensen (Foto: R. Snep).

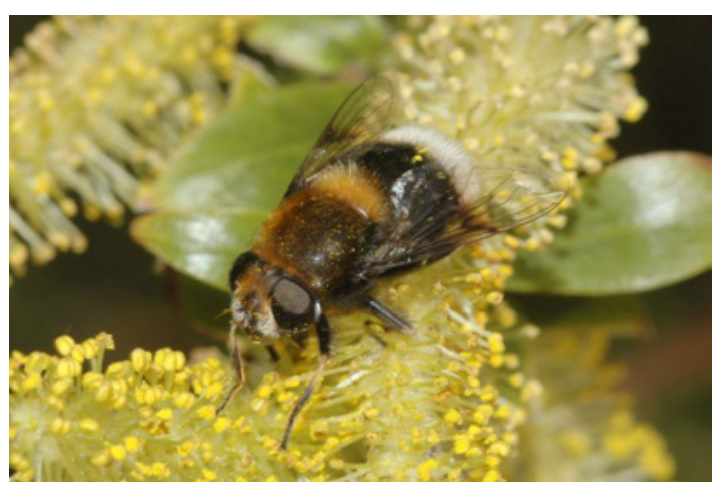

Voorbeeld van een wilde bestuiver: Hommelbijvlieg (Foto: R. Kleukers). 


\section{Omdat het mooi is}

Bloemrijke bermen en graslandjes, hagen en bomen zijn voedselbron voor bestuivende insecten. Ze geven kleur en geur aan de omgeving waarin we leven. Door onze omgeving in de stad en op het platteland bloemrijker te maken, wordt onze leefomgeving kleurrijker, mooier en interessanter: naast bestuivende insecten, waaronder vlinders zullen ook insectenetende vogels vaker te zien en te horen zijn.

\section{Om honing te kunnen blijven oogsten}

Iedereen kent de honingbij als producent van honing. En veel mensen zijn bezorgd over de achteruitgang van de honingbij. Door een bij-vriendelijke landschap te ontwikkelen, dragen we een steentje bij aan de overleving van ook de honingbijen en kunnen we blijven genieten van honing uit eigen streek.

\section{Omdat we kunnen er wat aan kunnen doen!}

Het is niet moeilijk om wat voor bestuivers te doen. Elke burger, organisatie of bedrijf die een tuin, een park of een stuk natuur bezit of beheert, kan een bijdrage leveren. Uw gazon vervangen door een bloemrijk grasland helpt al. Echt zoden aan de dijk zet het wanneer wordt samengewerkt door meerdere partijen die hun tuin of terrein bij-vriendelijker maken. Door samenwerking kan op landschapsniveau een robuust regionaal netwerk voor bijen, zweefvliegen en vlinders ontstaan, waarin de bestuiving, de productie van honing en beleving verzekerd zijn.

\subsection{Voor wie is deze handreiking?}

Deze handreiking is bedoeld voor alle actoren die betrokken zijn het Groene Cirkel Bijenlandschap en die een bijdrage willen leveren aan de doelstellingen daarvan. Hoe dat kan, daarvoor biedt dit rapport de benodigde informatie.

Bij het bij-vriendelijk inrichten van de omgeving denken veel mensen vooral aan bloemen. Terecht, want bijen, zweefvliegen en vlinders halen al hun voedsel uit bloemen. Vlinders hebben ook bepaalde waardplanten nodig waarop de rupsen groot kunnen worden. Maar met alleen bloemen en planten zijn de bestuivers er nog niet. Ze hebben ook plekken nodig om hun nesten te bouwen, zoals zandige plekken of holtes in oude bomen. En niet alle bloemen zijn even geschikt als voedsel, dus hoe stimuleert u geschikte planten en hoe zorgt u ervoor dat die bloemen er over een paar jaar nog steeds zijn?

Deze handreiking biedt praktische handvaten voor het inrichten van groene terreinen of terreinen die groen kunnen worden, zodat ze geschikt worden voor bestuivende insecten: bijen, zweefvliegen en vlinders. Voor de leesbaarheid duiden we alle bestuivende insecten aan als 'bijen'. Het Bijennetwerk is dus niet alleen voor bijen, maar voor een diversiteit van bestuivende insecten.

De handvaten zijn afgestemd op het Zuid-Hollandse klei- en veenweidelandschap in het Land van Wijk en Wouden en de Leidse Ommelanden en op het Duinlandschap in de Duin- en Bollenstreek.

Met deze handreiking willen we kennis op een publiekvriendelijk manier breed beschikbaar maken. In dit rapport staan daarom geen wetenschappelijke verwijzingen. Een verantwoording en meer achtergrond is te vinden in het bijlagerapport bij dit document.

Voor de leesbaarheid duiden we in deze handreiking de diversiteit aan bestuivende insecten (wilde bijen, honingbijen, zweefvliegen, vlinders) aan met: "Bijen".

Bij-vriendelijk beheer is niet alleen gunstig voor een zo groot mogelijke variatie aan wilde bijen, maar ook voor zweefvlieg- en vlindersoorten. 


\subsection{Toelichting op de verschillende versies van de handreiking}

In 2014 verscheen een eerste versie van deze handreiking, waarin naast een algemene beschrijving van het concept van het bijenlandschap, ook de eerste bouwsteen werd beschreven voor een bijenlandschap in het land van Wijk en Wouden, namelijk de bouwsteen "Bed \& Breakfast-gebied" (Van Rooij et al., 2014). Deze bouwsteen was gebaseerd op de eisen die wilde bijen en zweefvliegen aan hun leefomgeving stellen in het Laagveen-/Zeekleilandschap in het Land van Wijk en Wouden.

In 2016 verscheen een tweede versie met daarin ook de bouwstenen "Verbindend Landschap" en "Bijtankstation". Ook deze bouwstenen zijn gebaseerd op de eisen die bestuivers aan hun leefomgeving stellen in het Laagveen-/Zeekleilandschap. In deze versie waren ook kaarten van het land van Wijk en Wouden opgenomen die aangaven waar volgens berekeningen potentie was voor Bed \& Breakfastgebieden (Van Rooij et al., 2016a).

De voorliggende versie 3.0 is aangevuld met de ecoprofielen voor het Duinlandschap, inclusief de randvoorwaarden voor bouwstenen van het bijenlandschap in dit landschapstype.

\section{$1.4 \quad$ Leeswijzer}

In het volgende hoofdstuk wordt toegelicht wat de samenwerkende organisaties in de Groene Cirkel Bijenlandschap willen bereiken en hoe ze dat willen realiseren. Er worden bouwstenen voor het bijenlandschap gepresenteerd. Met deze bouwstenen kunnen deelnemers gericht gaan werken aan leefgebieden die de benodigde grootte, kwaliteit en samenhang hebben waardoor het resulterende netwerk van leefgebieden een grote diversiteit aan bestuivers kan huisvesten.

Hoofdstuk 3 geeft informatie over bij-vriendelijk beheer van groene infrastructuur en wat je kan doen om een terrein bij-vriendelijker in te richten.

In hoofdstuk 4 wordt voor een aantal terreintypen, die een belangrijke bijdrage kunnen leveren aan het bijennetwerk, specifieke informatie en voorbeelden gegeven hoe deze bij-vriendelijker beheerd of ingericht kunnen worden.

\section{Wat hebben bestuivende insecten nodig?}

\section{NESTELGELEGENHEID (Bed)}

Bijen moeten hun nesten kunnen bouwen, er zijn soorten die in de bodem hun nest bouwen, andere maken hun nest in bovengrondse structuren. Zweefvliegen maken geen nest, maar zetten eitjes af in de vegetatie of in rottende plantenresten. Ook vlinders leggen hun eitjes op planten, elke soort heeft zijn eigen waardplant(en).

\section{BLOEMEN (Breakfast)}

Voedsel, dus bloemen, moet van het vroege voorjaar tot de late zomer in ruime mate aanwezig zijn, liefst in zo groot mogelijke diversiteit. Onderbrekingen in de bloei moeten zo veel mogelijk voorkomen worden.

\section{ZON}

Bijen houden van warmte. Zowel de bloemen als de nestelplaatsen moeten een groot deel van de dag in de zon liggen.

\section{KLEINSCHALIGHEID}

Een gevarieerd landschap met een hoge diversiteit aan bloemen en bijen. Een bij-vriendelijk terrein is een beetje rommelig, niet te netjes!

\section{GEEN GIF}

De inzet van gif tegen insecten of 'onkruid' is zeer schadelijk voor bijen en dus uit den boze. 


\section{Eindelijk richting aan acties voor wilde bijen!}

Het dringt langzamerhand tot meer en meer mensen door dat bestuivers, zoals wilde bijen, zweefvliegen, motten en vlinders, een heel belangrijke rol spelen in onze ecosystemen. Ze bestuiven zo'n $90 \%$ van de wilde planten en een groot deel van de gewassen. In Nederland zijn o.a. appels, peren, aardbeien, blauwe bessen en kersen voor een aanzienlijk deel het resultaat van bestuiving door insecten. De media staan er vol van, maar tussen beseffen dat het belangrijk is, betekent nog niet dat er wat aan gedaan wordt.

Gelukkig willen veel mensen iets doen en gebeurt er van alles: bloemen inzaaien, bijenhotels aanschaffen etc. Helaas is de onderbouwing van

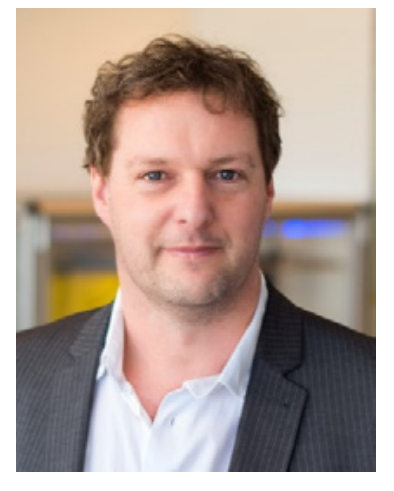
deze acties vaak vrij matig. Zo zijn er verschillende zaadmengsels 'voor bijen' op de markt waarin bloemen zitten waar bijen niks aan hebben. Deels is dat omdat er tot nu geen goede handleidingen beschikbaar waren en de kennis slecht verspreid te vinden is. Anderzijds is het lastig om kennis over de honderden soorten bestuivers begrijpelijk samen te vatten.

De ecoprofielen die nu opgesteld zijn als onderdeel van het Bij-zonder kleurrijk landschap-project, zijn een grote stap in de goede richting. Dat bijen B\&B nodig hebben (Bed \& Breakfast, oftewel nestplek en voedselaanbod), is allang bekend. Maar als het gaat om maatregelen voor bestuivers werden tot nu toe drachtplanten voor de honingbij meestal als uitgangspunt voor voedselaanbod genomen en werd niet nagedacht over nestplekken. Daar brengen de ecoprofielen verandering in. De profielen zijn elk representatief voor een andere groep bestuivers en nemen als basis de specifieke behoeften van die groep insecten. Hierdoor kunnen we, zelfs voor soorten waarvan we de specifieke behoeften nog niet voldoende begrijpen, een goed begin maken met herstel van hun leefgebied.

De ecoprofielen, samen met de gedetailleerde suggesties voor inrichting van leefgebied, zijn nauwkeurig op brede kennis van soorten en hun behoeften in elkaar gezet en zullen hopelijk gebruikt worden door iedereen die iets voor bijen en andere bestuivers wil doen. Dan kunnen we de positieve energie en drang tot actie voor bijen echt omzetten in verschil maken voor de bijen door een goede omgeving te creëren.

Prof. dr. Koos Biesmeijer, Wetenschappelijk Directeur Naturalis 


\section{Werken aan twee soorten netwerken}

Om de ambitie van een duurzaam bijenlandschap te realiseren, werken we aan twee soorten netwerken (Figuur 1):

- Het Bijenlandschap: een regionaal netwerk van bij-vriendelijke gebieden waar bestuivende insecten duurzaam kunnen voorkomen, duurzaam honing geoogst kan worden en mensen het kleurrijke landschap kunnen beleven.

- Het sociale netwerk van mensen, bedrijven en organisaties uit de regio die samen zorgen voor de realisatie van het regionale netwerk van bij-vriendelijke gebieden.

Deze twee netwerken zijn nauw met elkaar verbonden en beïnvloeden elkaar.

Geen enkele partij kan een regionaal bijenlandschap in zijn eentje realiseren. Wanneer overheden, bedrijven en burgers gaan samenwerken en gerichte actie ondernemen, wordt het wél mogelijk en gaat het landschap de gewenste landschapsdiensten leveren; behalve bestuiving, honing en een aantrekkelijk landschap liften ook andere diensten mee, bijvoorbeeld betere mogelijkheden om te sporten, te recreëren, te ontspannen, inspiratie op te doen etc. Een landschap waar volop bloemen en insecten te zien zijn, geeft ook een gevoel van een veilige, schone leefomgeving. Dat alles maakt de regio tot een aantrekkelijker gebied om te wonen, te werken en te recreëren.

Groene Cirkels wil met een sociaal netwerk het bijenlandschap realiseren en heeft daarom het initiatief genomen voor het Groene Cirkel-netwerk Bijenlandschap, met daarin overheden, burgerorganisaties en bedrijven. Door dit sociale netwerk te voorzien van de benodigde kennis over de bouwstenen (zoals in deze handreiking), kunnen de regionale partijen gericht en effectief samenwerken aan de realisatie van het bijenlandschap.

Met het bijenlandschap werken we dus niet alleen aan een netwerk voor bijen, maar ook aan een netwerk met regionale partijen die dat samen kunnen organiseren.

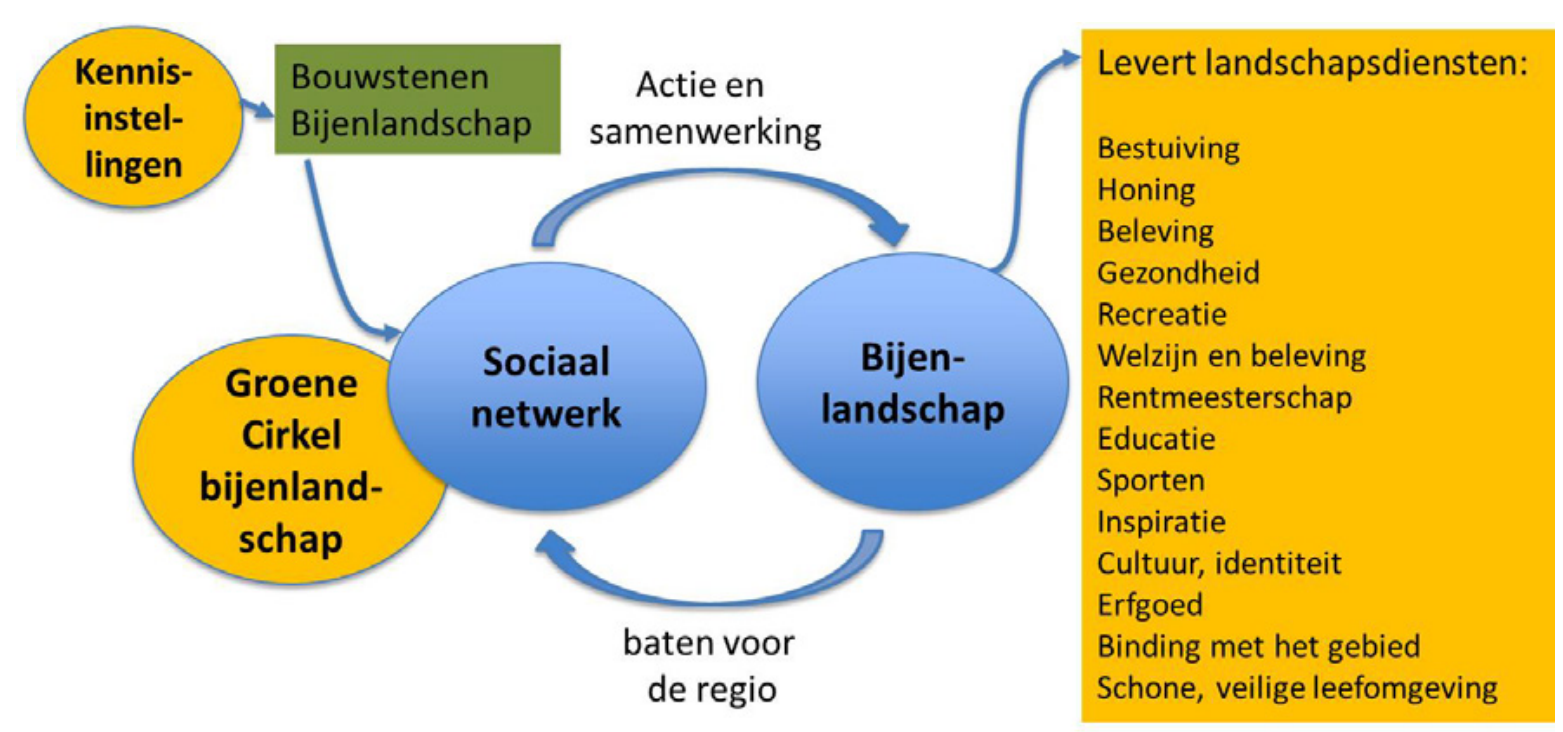

Figuur 1 Het sociale netwerk en het ecologische netwerk voor bijen in het bijenlandschap hangen nauw met elkaar samen. Groene Cirkels ontwikkelt daarom beide netwerken. 


\subsection{Het sociale netwerk: initiatieven in de regio}

Om tot een regionaal netwerk voor bestuivende insecten te komen, kan verder gebouwd worden op initiatieven die er al lopen. Een aantal gemeenten, bedrijven en organisaties is al bezig met het bijvriendelijk inrichten en beheer van hun terrein. Anderen hebben de ambitie om dat te gaan doen en zijn nog bezig om partners of financiering te vinden.

\section{Enkele voorbeelden van initiatieven en initiatiefnemers:}

- Initiatief 'Boeiend Bloeiend Bedrijventerrein' door BIZ Grote Polder: bij-vriendelijk maken van het bedrijventerrein.

- Initiatief Archeon en de gemeente Alphen: bij-vriendelijk maken van het Archeon-terrein aan en verbinden met groen in de stad.

- Initiatieven 'Elfenbaan' en 'Bijenbosje' door Zuid-Hollands landschap en Rijkswaterstaat: inrichting en beheer van de Elfenbaan, een stuk land tussen de spoorweg en de N11 bij-vriendelijk maken en het aanleggen en beheren van een bosje voor bijen.

- Pilot 'bij-vriendelijk bermbeheer N11' door Rijkswaterstaat, proef hoe ze bermen langs rijkswegen bijvriendelijker kunnen beheren.

- Initiatief 'Groene linten' door Boerenorganisatie Groene Klaver, gemeente Alphen a/d Rijn en IVN: het realiseren van bij-vriendelijke verbindingen in het buitengebied.

- Initiatief 'Bijen in de buurt' door Fonds 1818, gemeenten en vrijwilligers van 'De groene motor'; het realiseren van bij-vriendelijke verbindingen in het stedelijke gebied in tuinen.

- Initiatief 'Biodiversiteit op het Bedrijventerrein' door Heineken: het bij-vriendelijk inrichten en beheren van het Heineken-terrein in Zoeterwoude.

- Initiatief 'Bentwoud bij-vriendelijk' door Staatbosbeheer, gemeente Zoetermeer en Hoogheemraadschap van Rijnland e.a.

En zo zijn er nog vele andere initiatieven gaande en in voorbereiding! Meer informatie hierover is te vinden op: www.groenecirkels. $\mathrm{nl} / \mathrm{nl} /$ groenecirkels/Themas/Leefomgeving/Project-Bijenlandschap.htm

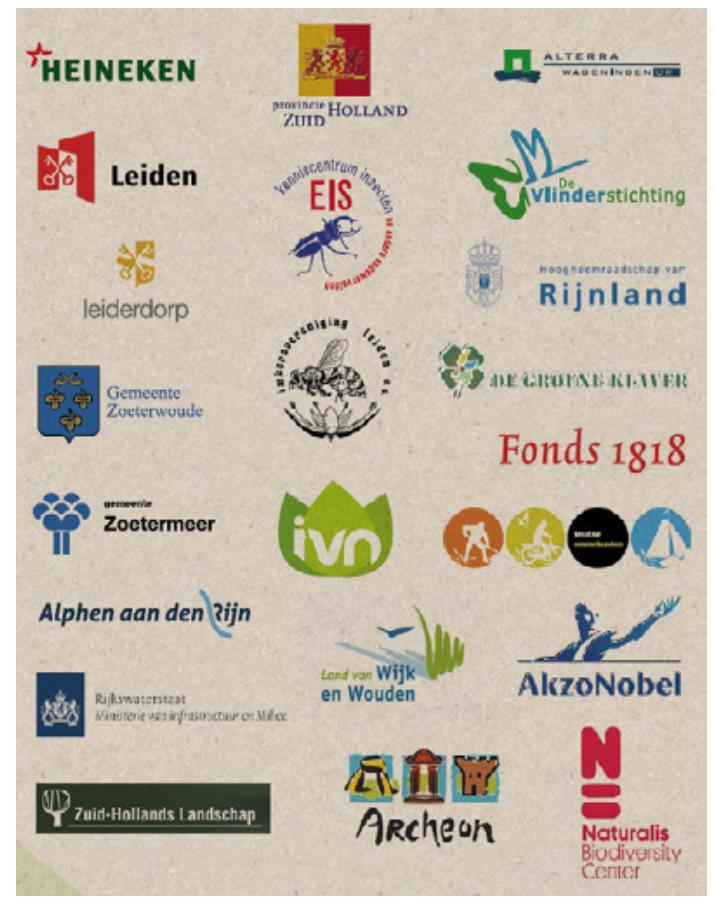




\subsection{Het bijennetwerk}

\subsubsection{Een duurzaam netwerk voor bestuivende insecten}

\section{Bouwstenen voor een bijennetwerk}

Het bijennetwerk waarin bestuivende insecten duurzaam kunnen voorkomen, bouwen we op uit een aantal bouwstenen (Figuur 2):

'Bed \& Breakfast-gebieden' (B\&B):

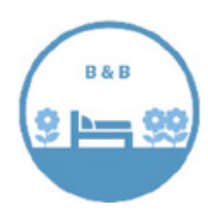

Een gebied waar een diverse gemeenschap van bestuivende insecten voldoende nestgelegenheid en gedurende het hele jaar voedsel vindt. Hiervoor is relatief een groot oppervlak aan voedsel- en nestplekken nodig van voldoende kwaliteit, groot genoeg om variatie in bijvoorbeeld het weer op te vangen. Hierdoor is men ieder jaar verzekerd van een gevarieerde bevolking van bestuivende insecten.

\section{'Verbindend Landschap':}

Het landschap tussen B\&B's met voedselhabitat en nestplekken. De plekken zijn te klein voor het herbergen van een $B \& B$, maar ze zorgen voor verbinding van $B \& B$-gebieden, waardoor het bijennetwerk robuuster wordt. Deze verbindingen in het landschap stellen

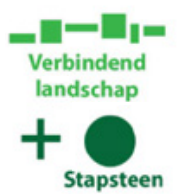
de bestuivende insecten in staat om nieuwe gebieden te bereiken en zich (weer) te vestigen na extreme weersomstandigheden of ziekten en om mee te schuiven met opschuivende klimaatzones. Het Verbindend Landschap kan bijvoorbeeld bestaan uit bloemrijke bermen, slootkanten of andere kleine terreinen. Als een soort een grote afstand tussen B\&B-gebieden moet overbruggen, is er hier en daar een stapsteen nodig in de verbinding: een klein leefgebiedje dat als springplank dient om het volgende deel van een traject te kunnen overbruggen.

\section{'Bij-tankstations':}

Kleine bij-vriendelijke plekken, zoals tuinen, balkons en kleine parkjes, die geïsoleerd van het netwerk zijn gelegen. Ook deze plekjes, in de stad of het veenweidegebied waar weinig bloemen en struiken te vinden zijn, kunnen bijdragen aan het netwerk: het maakt de stad of het landschap beter te overbruggen voor bijen, vlinders en zweefvliegen. Ze kunnen even wat voedsel bijtanken en weer doorvliegen, op zoek naar andere voedselbronnen of nieuwe leefgebieden.

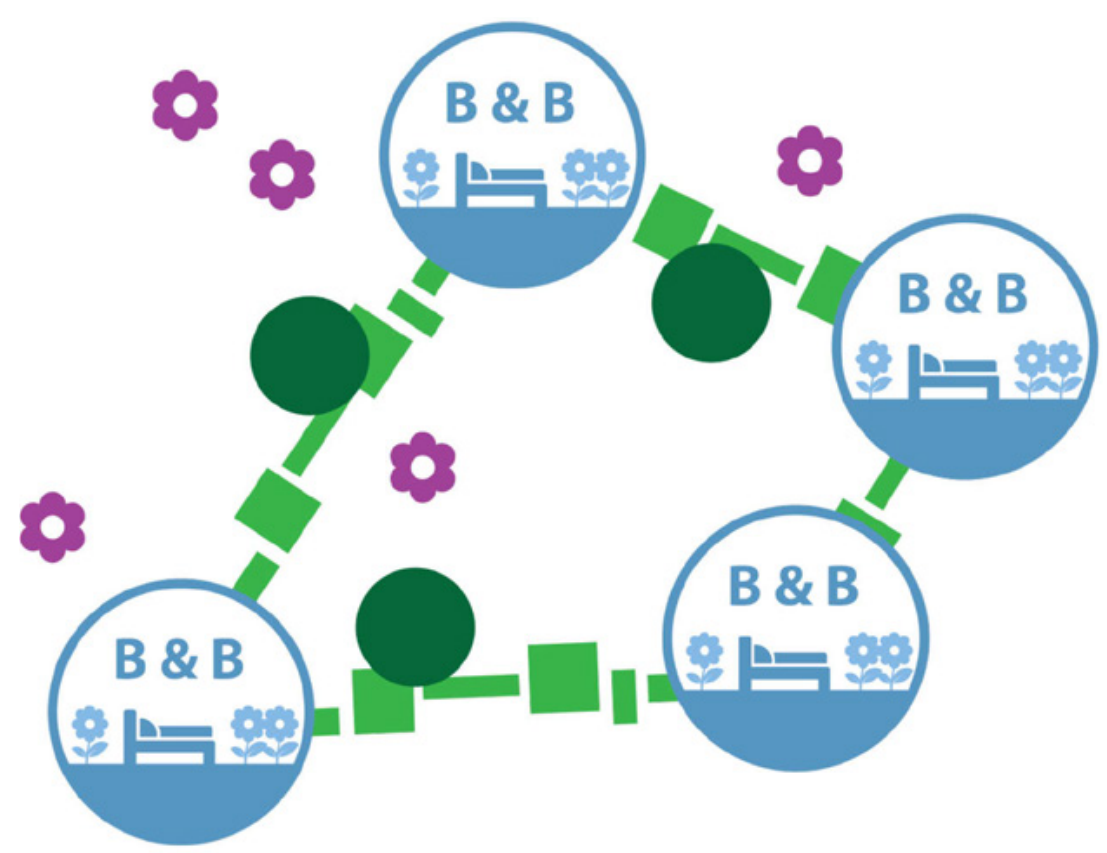

Figuur 2 Schematische weergave van gewenste samenhang tussen de bouwstenen van het Bijenlandschap. 


\section{Verschillende typen landschappen huisvesten verschillende soorten bestuivers}

De diversiteit aan bestuivende insecten en de soorten die in een gebied kunnen voorkomen, zijn niet overal in Nederland gelijk. Uit onderzoek bleek dat dit vooral samenhangt met de hoeveelheid natuur in een gebied: hoe meer natuur, hoe meer soorten bestuivers. Daarnaast bleek het type landschap heel bepalend voor samenstelling van de bevolking van bestuivende insecten. Elk type landschap kenmerkt zich door een specifieke diversiteit aan bestuivers die er voor kunnen komen. Soorten die minder specifieke eisen aan hun leefomgeving stellen, kunnen ook in meerdere typen landschap hun leefgebied vinden. Een aantal soorten, met name uit de hommelgroep, is zo weinig kieskeurig dat ze overal in Nederland te vinden is, zelfs in intensief gebruikte landbouwgebieden (Ozinga et al., 2018; Figuur 3).

Het land van Wijk en Wouden kenmerkt zich door een afwisseling van laagveen- en zeekleilandschap. In het vervolg van dit rapport zullen we voor het gemak naar dit gebied verwijzen als 'laagveenlandschap'. Een flink aantal (vaak relatief nieuwe) partners in het Groene Cirkelbijenlandschap zijn ten westen van het laagveenlandschap gesitueerd, in het duinlandschap.

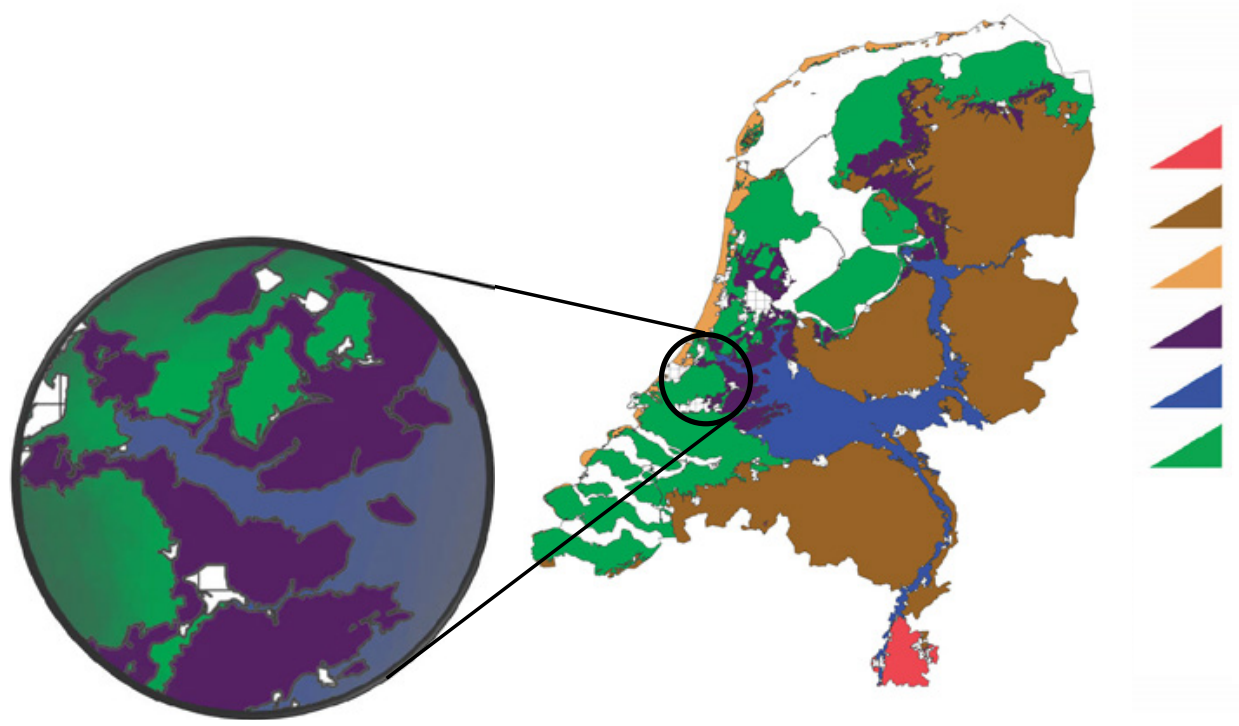

Heuvellandschap Zandlandschap Duinlandschap Laagveenlandschap Rivierenlandschap Zeekleilandschap

Figuur 3 In verschillende typen landschappen komen verschillende soorten bestuivers voor (naar Ozinga et al., 2018).

\section{De vele soorten bestuivers gegroepeerd in enkele ecoprofielen}

Iedere soort stelt andere eisen aan $z^{\prime} n$ omgeving. Het is ondoenlijk om voor de honderden soorten of zelfs voor de tientallen soorten - bijen, zweefvliegen en vlinders die in een bepaald landschapstype voor kunnen komen, apart een habitatnetwerk (of een bouwsteen daarvan) te ontwerpen waar ze duurzaam voor kunnen komen. Van de andere kant heb je inzicht nodig in de ruimtelijke eigenschappen van al deze soorten (hoe ver kunnen ze vliegen, hoeveel voedselgebied hebben ze nodig etc.) om een netwerk te kunnen ontwerpen dat voor een hoge diversiteit van bestuivende soorten wérkt. Daarom hebben we de veelheid aan soorten van bestuivende insecten die in Wijk en Wouden en het aangrenzende duinlandschap kunnen voorkomen, teruggebracht tot een beperkt aantal 'ecoprofielen'. Een ecoprofiel is een gemeenschap van bijen, zweefvliegen en vlindersoorten die ongeveer dezelfde eisen stelt aan voedselhabitat en nestplekken in het landschap. Op basis van de eigenschappen van de soorten die tot eenzelfde ecoprofiel behoren, hebben we de minimumeisen opgesteld voor de bouwstenen en voor het netwerk dat daarmee kan worden opgebouwd (zie Tabel 1 en 2 voor het Laagveenlandschap en Tabel 2 en 3 voor het Duinlandschap). 
Grazig

Grazig
Droog

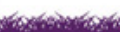

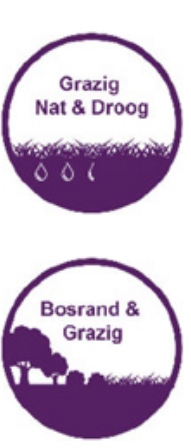

Ecoprofiel 'Grazig Droog': omvat soorten die open terreinen met een opkomende kruidenbegroeiing nodig hebben, afgewisseld met kale plekken.

Ecoprofiel 'Grazig Nat en Droog': omvat soorten die een combinatie van droog en nat grasland met open plekken nodig hebben.

Ecoprofiel 'Bosrand en Grazig': omvat soorten die bomen en struikgewas nodig hebben, in combinatie met droge, grazige plekken met hier en daar kale stukjes.

Tabel 1 Overzicht van de ecoprofielen van Laagveenlandschap die zijn gebruikt om de bouwstenen te voorzien van concrete vuistregels voor benodigde grootte, kwaliteit en samenhang van leefgebied.

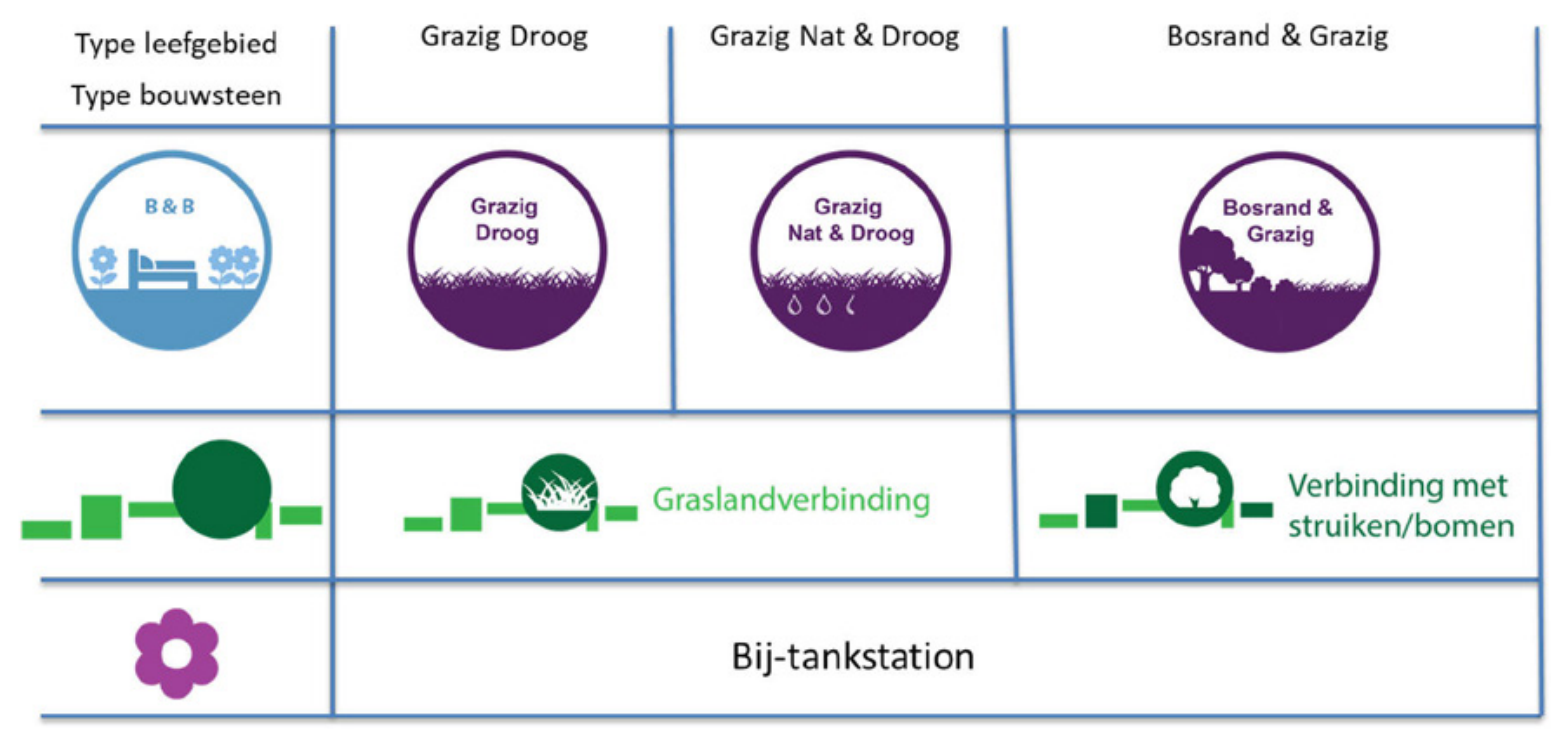


Ecoprofiel 'Open Duin': omvat soorten die een dynamisch en reliëfrijk duinlandschap nodig hebben met kleinschalige mozaïeken van open zand, grasland, heide, vochtige duinvalleien, solitaire bomen of struiken.

Ecoprofiel 'Grazig Droog': omvat soorten die open terreinen met een opkomende kruidenbegroeiing nodig hebben, afgewisseld met kale plekken.

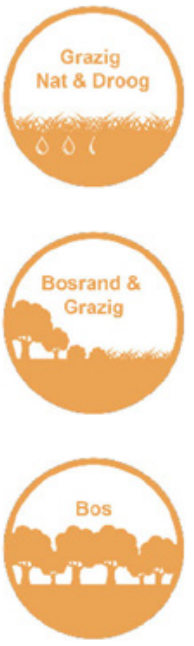

Ecoprofiel 'Grazig Nat \& Droog': omvat soorten die een combinatie van droog en nat grasland met open plekken nodig hebben.

Ecoprofiel 'Bosrand \& Grazig': omvat soorten die bomen en struikgewas nodig hebben, in combinatie met droge, grazige plekken met hier en daar kale stukjes.

Ecoprofiel 'Bos': omvat zweefvliegen die vrijwel alleen in (liefst oude) bossen of parken voorkomen. Veel van deze soorten zijn van bomen en struiken afhankelijk voor hun voortplanting (bed).

Tabel 2 Overzicht van de ecoprofielen van Duinlandschap die zijn gebruikt om de bouwstenen te voorzien van concrete vuistregels voor benodigde grootte, kwaliteit en samenhang van leefgebied.

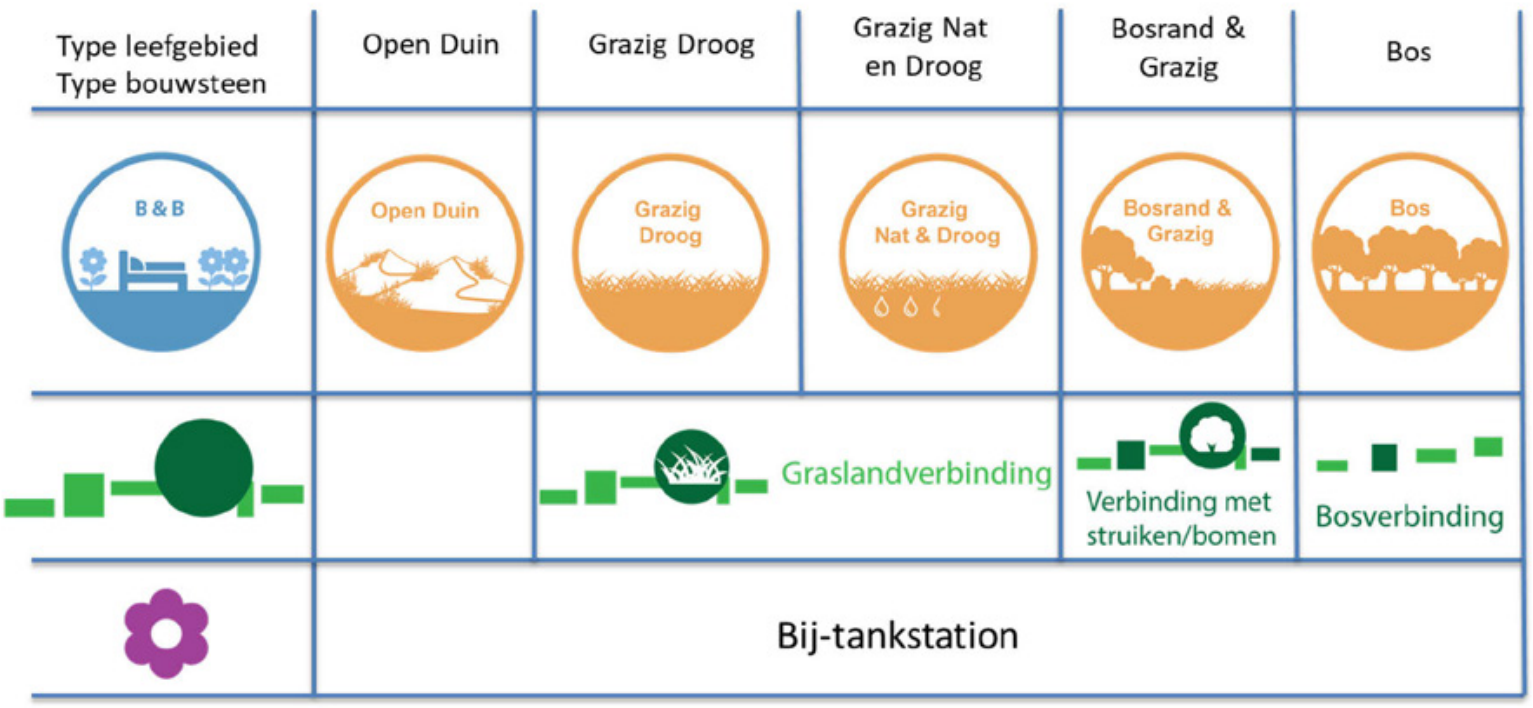


Voor ecoprofielen 'Grazig Droog' en 'Grazig Nat \& Droog': soorten van deze ecoprofielen hebben met elkaar gemeen dat ze grasland met open plekken nodig hebben. Nat of droog grasland maakt voor het Verbindend Landschap dus niet zoveel uit.

$\square=\begin{aligned} & \text { Verbinding met } \\ & \text { struiken/bomen }\end{aligned}$ $\boldsymbol{\square}=$ Bosverbinding
Voor soorten van ecoprofiel 'Bosrand \& Grazig'; soorten die bomen en struikgewas nodig hebben, in combinatie met droge grazige plekken met hier en daar kale stukjes.

Voor soorten van ecoprofiel 'Bos'; de zweefvliegen van ecoprofiel 'Bos' zijn erg mobiel. Voor deze soorten geldt dat zowel bos als grazig habitat kan dienen als verbindend landschap.

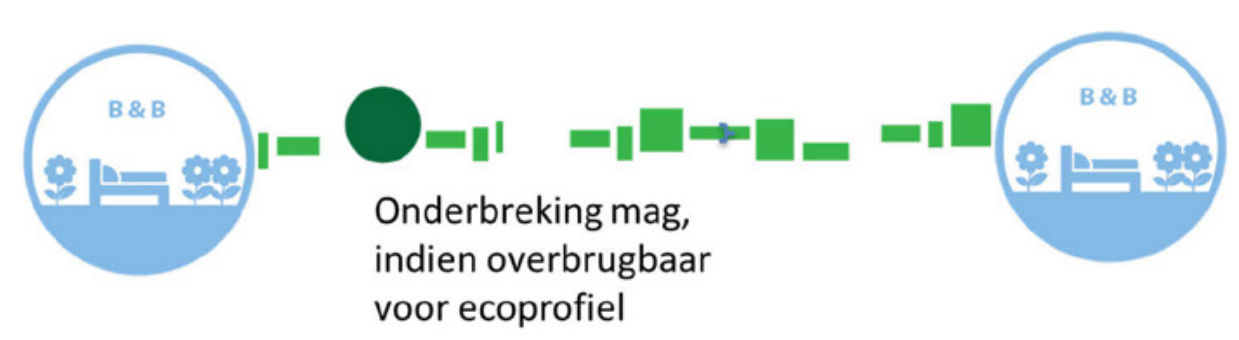

Figuur 4 Schematische weergave van de ruimtelijke randvoorwaarden voor de bouwsteen 'Verbindend Landschap'.

Ecoprofiel voor kleine, geïsoleerde plekken:

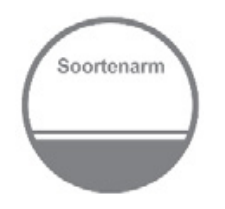

Ecoprofiel 'Soortenarm': hieronder vallen soorten die erg mobiel en niet kieskeurig zijn en al snel een Vlinderstruik of Rode klaver gevonden hebben om voedsel te kunnen bijtanken.

Meer informatie over de ecoprofielen

Meer informatie over de ecoprofielen en hoe deze te gebruiken bij het plannen van een regionaal netwerk is te vinden in het bijlagerapport bij deze handreiking: 'Ecoprofielen voor het plannen van een regionaal netwerk voor bestuivende insecten in laagveen/zeeklei- en duinlandschap' (Van Rooij, 2020).

\section{Wanneer is een gebied een B\&B-gebied?}

In Tabel 2 is aangegeven wat er voor de soorten behorende tot de genoemde ecoprofielen minimaal nodig is voor een Bed \& Breakfast-gebied: tien nestplekken en 10 ha geschikt voedselhabitat. De benodigde oppervlakte aan voedselgebied hoeft hierbij niet per se aaneengesloten te zijn, maar kan ook bestaan uit een optelsom van bermen, plantsoenen en overhoekjes. Ook kunt u kijken naar voedselhabitat en nestplekken die in aangrenzende terreinen aanwezig zijn of kunnen ontstaan. Zolang de voedselhabitat maar niet verder dan $500 \mathrm{~m}$ van de nestplekken verwijderd is, want dan wordt het voedsel voor veel soorten onbereikbaar. Met deze ruimtelijke normen kunt u, door met de ogen van een ecoprofiel naar het landschap te kijken, beoordelen wat er nog nodig is om soorten van een ecoprofiel duurzaam te laten voorkomen in een Bed \& Breakfast-gebied.

Grofweg kunt u een gebied als volgt beoordelen: als er binnen een vierkante kilometer (= 100 ha) minstens tien geschikte nestplekken zijn en zo'n $10 \%$ van de oppervlakte bestaat uit planten of bomen die voedselbron is voor de soorten behorend tot een ecoprofiel, kan het gebied fungeren als een Bed \& Breakfast voor de soorten van dat ecoprofiel. Dit bij een_bij-vriendelijke inrichting en 
beheer (zie volgende hoofdstukken). Als er onvoldoende nestplekken zijn en/of voedselhabitat aanwezig is, heeft $u$ een idee wat er aanvullend nodig is om een Bed \& Breakfast-gebied te laten ontstaan.

De ruimtelijke normen uit Tabel 3 en 4 zijn afgeleid uit bestaande expert- en literatuurkennis van de afzonderlijke soorten die onder de ecoprofielen vallen en uit beschikbare kennis van vergelijkbare insecten. Deze vuistregels helpen om doelgericht voor een groot deel van de bestuivers effectieve maatregelen te kunnen nemen, zonder dat u zich specifiek op één soort richt of $u$ te verliezen in een veelheid aan soorten.

\section{Wanneer fungeert een tussenliggend gebied als Verbindend Landschap?}

'Verbindend Landschap' is een bloemrijke corridor tussen Bed \& Breakfast-gebieden, met hier en daar nestelplekken, waar bijen kunnen voorkomen en waarlangs ze zich kunnen verplaatsen en nieuwe leefgebieden bereiken.

We onderscheiden drie typen Verbindend Landschap:

- Een Graslandverbinding die B\&B-gebieden voor de ecoprofielen 'Grazig Droog' en 'Grazig Nat' met elkaar in verbinding kan stellen;

- Verbinding met struiken/bomen, die B\&B-gebieden voor ecoprofiel 'Bosrand \& Grazig' aan elkaar koppelt.

- Verbinding met bos en grazig, die B\&B-gebieden voor ecoprofiel 'Bos' aan elkaar koppelt.

Verbinding van B\&B-gebieden voor de soorten van hetzelfde ecoprofiel is altijd gunstig. Ook verbinding tussen $B \& B$ 'droog grasland' voor de soorten van het ecoprofiel Pionier en B\&B 'combi nat en droog grasland' van het ecoprofiel Zweefvlieg heeft zin. Terreinen zijn altijd divers en ook in droog grasland kunnen er nattere plekken voorkomen die net goed zijn voor bepaalde soorten. Ook zijn gradiënten, geleidelijke overgangen tussen bijvoorbeeld nat en droog, gunstig voor een hoge diversiteit aan soorten. Hoe meer populaties een soort in het gebied kan stichten, hoe groter de kans dat deze een goede plek treft waar de soort duurzaam kan voorkomen.

Graslandverbinding: een graslandverbinding bestaat niet alleen uit gras, maar vooral uit bloemrijke kruidenvegetatie met een grote soortenrijkdom.

Verbinding met struiken/bomen: een verbinding met struiken en bomen verbindt B\&B's van het ecoprofiel 'Bosrand \& Grazig' met elkaar. Insecten die aan bomen en struiken gebonden zijn, deinzen er vaak voor terug om grote, open gebieden over te steken. Houtwallen en lanen kunnen de verspreiding van zulke insecten stimuleren, omdat deze hun vlucht letterlijk in goede banen leiden. Liefst is er variatie in breedte en dichtheid van de struik- en boomlaag en zijn er geleidelijke overgangen in hoogte. De randen zijn bij voorkeur niet recht, maar enigszins 'meanderend', zodat beschutte inhammen ontstaan.

Bosverbinding: de zweefvliegen van ecoprofiel 'Bos' zijn erg mobiel. Voor deze soorten geldt dat zowel bos als grazig habitat kan dienen als verbindend landschap. Bomen of stapstenen zijn daarbij niet per se nodig, zoals bij de andere ecoprofielen wel het geval is. Zolang zweefvliegen onderweg eten kunnen vinden, blijven ze doorvliegen tot ze in een nieuw gebied komen waar ze ook eitjes kunnen leggen. De maximale afstand tussen habitatplekken is ingeschat op $500 \mathrm{~m}$.

Verbindend Landschap stelt soorten in staat om van het ene B\&B-gebied het andere te bereiken en te bevolken. Dat is van belang als een populatie door extreme (weers)omstandigheden toch plaatselijk verdwenen is of als soorten met hun leefgebied mee moeten schuiven met de opschuivende klimaatzones.

De grote meerderheid van bijen, zweefvliegen en vlinders hebben het volgende nodig om zich over grotere afstanden te kunnen verplaatsen (Figuur 3):

- Geschikt habitat in het Verbindend Landschap is ten minste $3 \mathrm{~m}$ breed en bij bermen $5 \mathrm{~m}$ breed. Dit laatste omdat habitat in de eerste $2 \mathrm{~m}$ van de berm langs een weg onbruikbaar is voor de insecten vanwege windvlagen door langsrijdende auto's. 
- De maximale afstand tussen habitatplekken in het Verbindend Landschap is afhankelijk van de maximaal overbrugbare afstand voor soorten van een specifiek ecoprofiel.

- De afstand tussen Bed en Breakfast-gebieden die met een Graslandverbinding of een verbinding met struiken/bomen overbrugd kan worden, is maximaal $1 \mathrm{~km}$. Als deze gebieden verder uit elkaar zijn gelegen, dienen er een of meer stapstenen (minimaal om de kilometer) te worden gerealiseerd. Een stapsteen bestaat uit 0,5 ha geschikt habitat voor vlinders, bijen en zweefvliegen van het ecoprofiel waarvoor het Verbindend Landschap een verbinding vormt.

Tabel 3 Vuistregels voor minimaal benodigd voedselhabitat en nestplekken voor een Bed \& Breakfast-gebied voor soorten van de ecoprofielen van Laagveenlandschap.

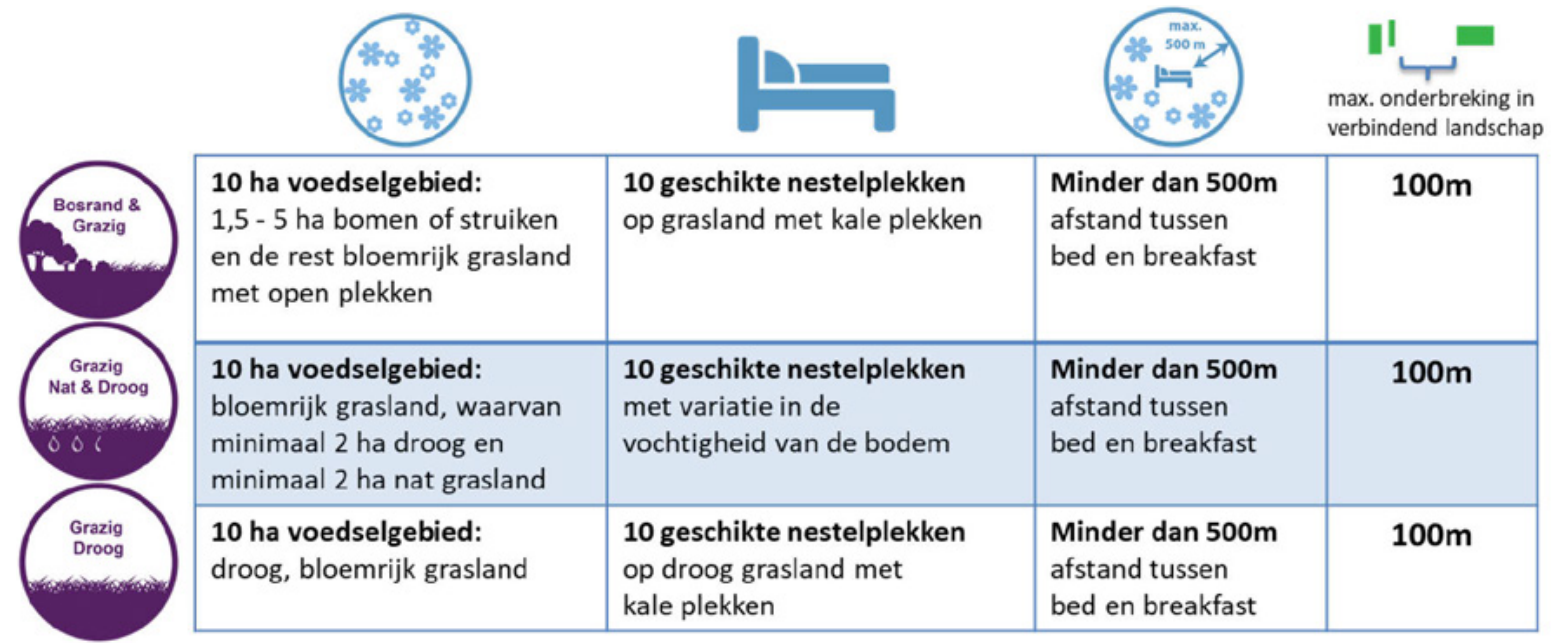

Tabel 4 Vuistregels voor minimaal benodigd voedselhabitat en nestplekken voor een Bed \& Breakfast-gebied voor soorten van ecoprofielen van Duinlandschap.

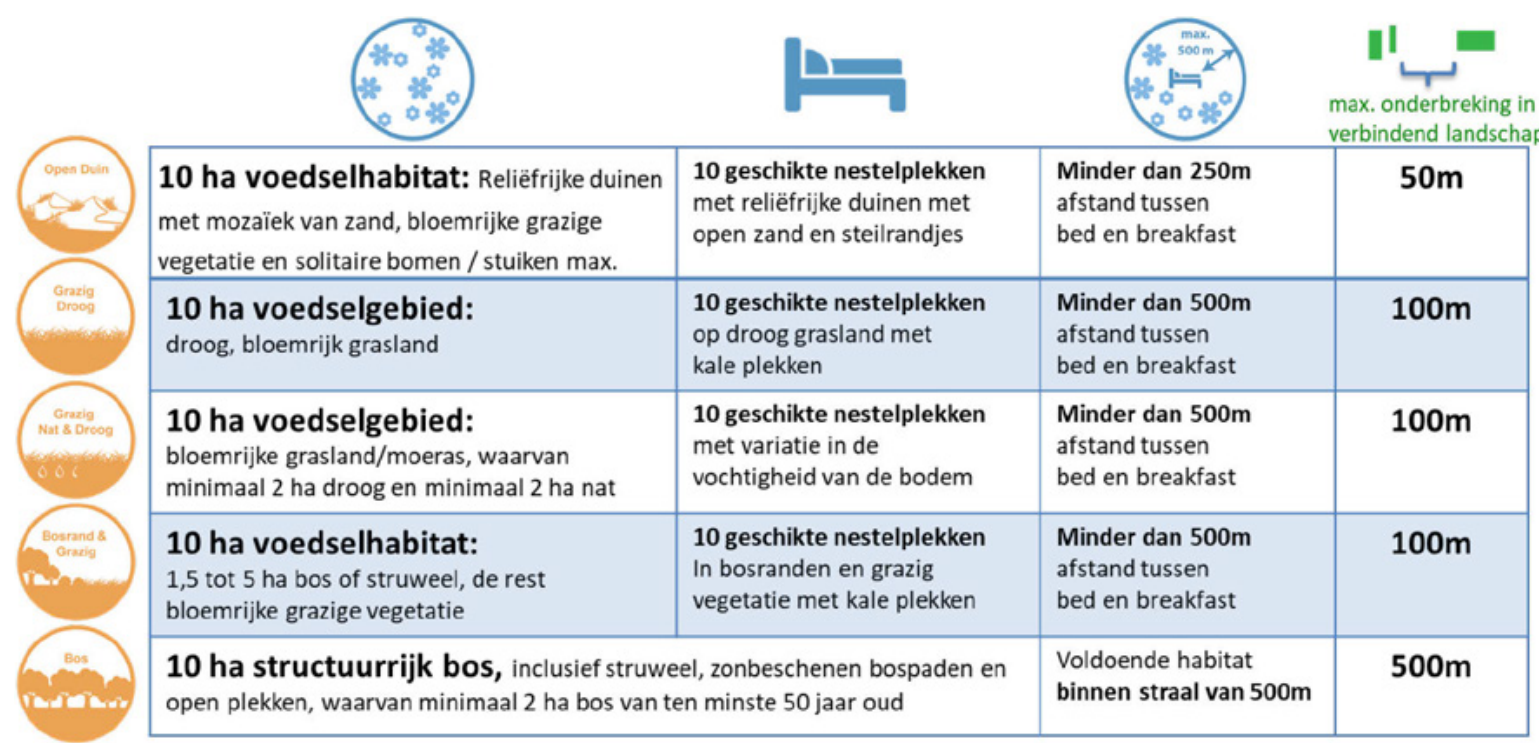


De Vlinderstichting en de Nederlandse

Bijenhoudersvereniging leggen samen met veel vrijwilligers zogenaamde 'idylles' aan. Dit zijn bloemrijke plekken in de stad, het buitengebied of langs sloten of wegen, voor vlinders, bijen en mensen. Deze idylles zijn qua grootte vergelijkbaar met stapstenen en kunnen als zodanig deel uitmaken van Verbindend Landschap. Als een Idylle niet gelegen is in Verbindend Landschap kunnen ze dienen als Bij-tankstation (www.vlinderstichting.nl/idylle/).

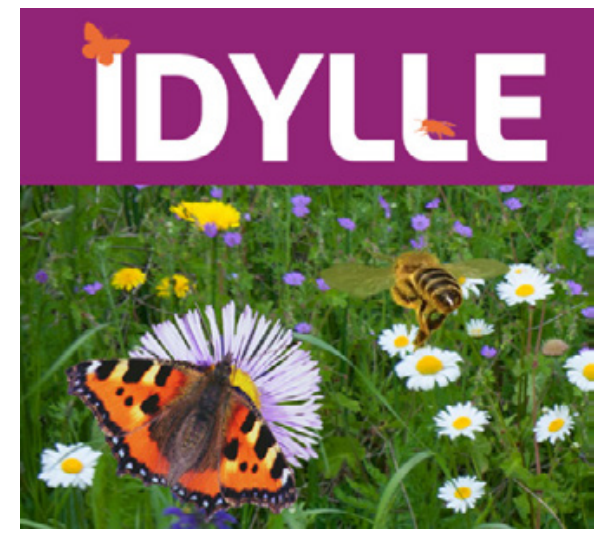

\subsubsection{Duurzame productie van honing}

Door het plaatsen van bijenkasten in een Bed \& Breakfast-gebied kan er ook honing geoogst worden. Wilde bijen concurreren in zekere mate met honingbijen om het beschikbare voedsel. Een te groot aantal bijenkasten op een klein gebied zal ten koste gaan van de wilde bijen en zweefvliegen. Om de diversiteit aan bestuivende soorten zo groot mogelijk te houden en ook honing te kunnen oogsten, hanteren we het maximum van drie bijenkasten per vierkante kilometer/per Bed \& Breakfast. In een gebied met veel (mannelijke) wilgen, die veel stuifmeel leveren, kunnen dit er eventueel meer zijn. Deze normen hanteren de terreinbeherende organisaties als Natuurmonumenten en Staatsbosbeheer als richtlijnen voor de plaatsing van bijenkasten in natuurterreinen.

\subsubsection{Een 'beleefbaar' landschap}

Behalve dat $u$ iets wilt bijdragen aan duurzame bestuiving in de regio, wilt u misschien ook dat uw terrein aantrekkelijker wordt en dat bewoners en bezoekers de natuur, bloemen en insecten kunnen beleven. Veel bij-vriendelijke maatregelen fleuren uw gebied sowieso op. In de volgende hoofdstukken vindt $u$ tips voor inrichting en beheer om uw terrein zo aantrekkelijk mogelijk te maken, niet alleen voor bestuivende insecten, maar dus ook voor mensen.

\subsubsection{Potentie voor Bed \& Breakfast-gebieden}

Waar liggen er in het gebied mogelijkheden voor een B\&B-gebied en op welke plekken is er onvoldoende potentieel leefgebied voor de soorten van de ecoprofielen? Dit is voor bepaald voor het Laagveenlandschap met een geografisch informatiesysteem (GIS) aan de hand van de vuistregels in Tabel 3 en kaarten met landgebruik en bodemgegevens van het gebied. De resultaten zijn weergegeven in Figuur 6 t/m 9 voor respectievelijk de ecoprofielen 'Bosrand \& Grazig', 'Grazig Nat \& Droog' en 'Grazig Droog'.

In de kaarten zijn die gebieden met blauw aangegeven, waar in potentie kan worden voldaan aan de vuistregels voor een B\&B-gebied voor het betreffende ecoprofiel (Figuur 5). Dus ook een gebied aan de rand van het blauwgekleurde gebied kan het centrum zijn van een B\&B-gebied.

Het ecoprofiel 'Bosrand \& Grazig' heeft de combinatie van grasland met bos of struikgewas nodig. Grasland is er in het gebied tussen Alphen aan den Rijn, Leiden en Zoetermeer in overvloed. Bos en struiken zijn voor dit ecoprofiel met name bepalend of een gebied in potentie voldoende bos en grasland in de nabijheid heeft om als B\&B-gebied te kunnen fungeren (Figuur 6). De gebieden die in Figuur 6 niet blauw zijn gekleurd, hebben in hun omgeving onvoldoende bos en struiken, de beperkende factor voor dit ecoprofiel, zoals omschreven in Tabel 3 om aan de voorwaarden voor een B\&B te voldoen. 
Bos en grasland vormen ingrediënten voor een 'Graslandverbinding/ verbinding met struiken/bomen' voor de soorten van het ecoprofiel 'Bosrand \& Grazig'. Deze vegetatietypen zijn daarom ook weergegeven op de kaart in Figuur 6. De resulterende kaart geeft daarmee ook een beeld waar een Graslandverbinding met struiken/bomen tussen B\&B-gebieden voor de bestuivers van het ecoprofiel 'Bosrand \& Grazig' gerealiseerd zou kunnen worden.

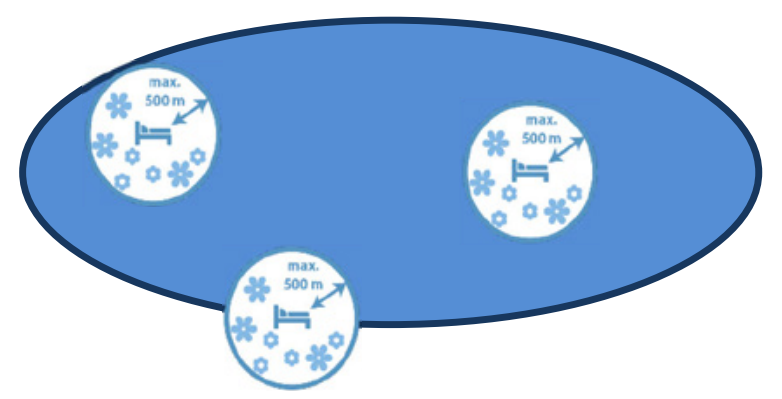

Figuur 5 Schematische weergave van de wijze waarop het gebied met potentie voor een B\&B geïnterpreteerd dient te worden: elke plek in het blauwe gebied heeft voldoende potentieel leefgebied binnen een straal van 55 m om als een B\&B-gebied te kunnen fungeren en kan het centrum zijn van een dergelijk gebied.

Het ecoprofiel 'Grazig Nat \& Droog' heeft de combinatie van nat met droog grasland nodig. Nat grasland is in het gebied in overvloed aanwezig, droog grasland is veel schaarser, en is daarom bepalend of een gebied in potentie als B\&B-gebied voor dit ecoprofiel kan fungeren (Figuur 7).

Dat droog grasland in het gebied schaars is, is ook goed te zien aan de potentiekaart voor B\&Bgebieden voor het ecoprofiel 'Grazig Droog' (Figuur 8). De oppervlakte van potentiële B\&B-gebieden is voor dit ecoprofiel veel kleiner dan voor de die van 'Bosrand \& Grazig' en 'Grazig Nat \& Droog'.

Het gebied tussen de B\&B-gebieden voor de ecoprofielen 'Grazig Nat \& Droog' en 'Grazig Droog' is van belang als Verbindend Landschap tussen deze B\&B-gebieden, zodat bestuivende soorten zich van het ene naar het andere B\&B-gebied kunnen verplaatsen. Alle grasland, droog en nat, is in principe geschikt om een graslandverbinding te realiseren. Alle grasland is weergegeven in Figuur 7. Zo wordt duidelijk welke mogelijke Graslandverbindingen voor de bestuivers van deze ecoprofielen gerealiseerd zouden kunnen worden. 


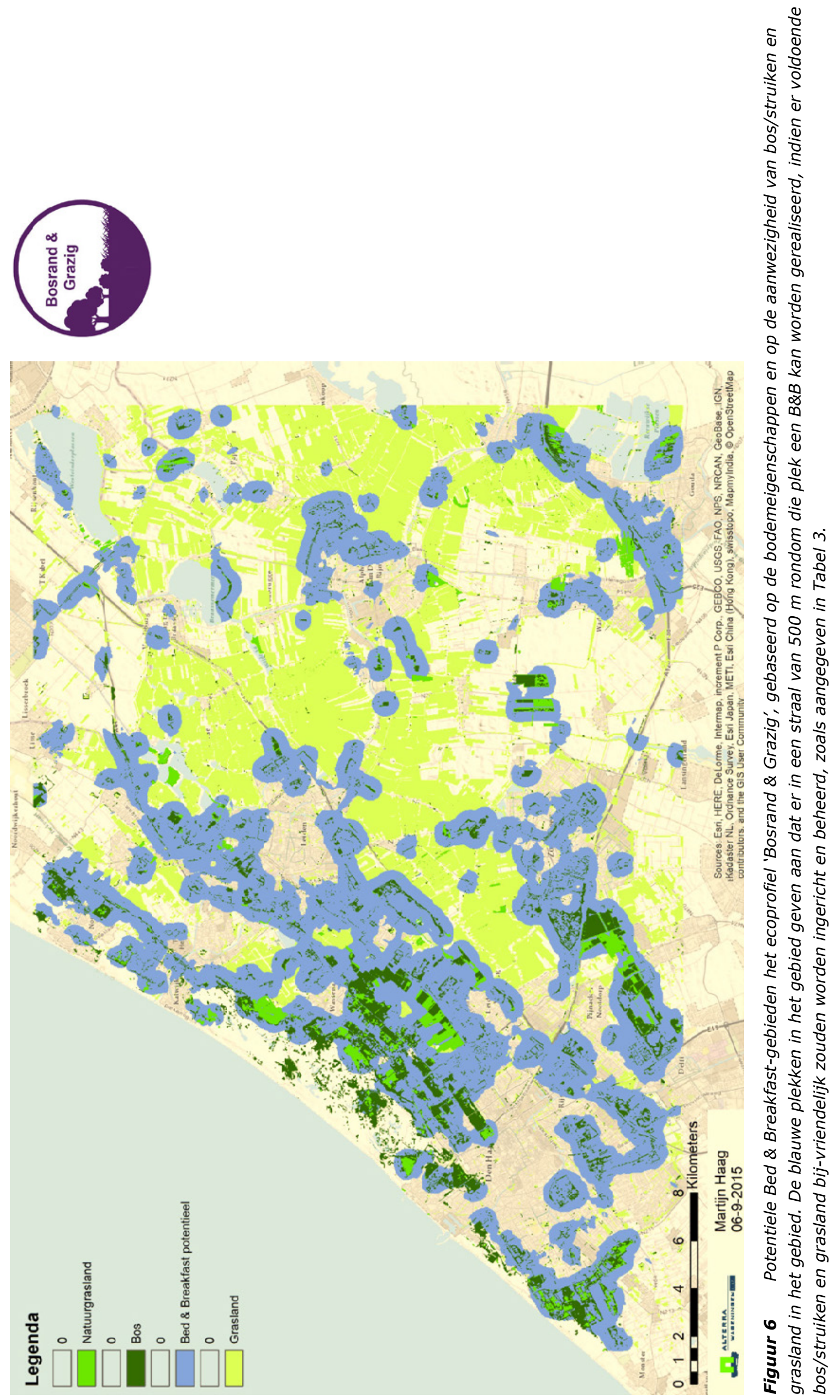




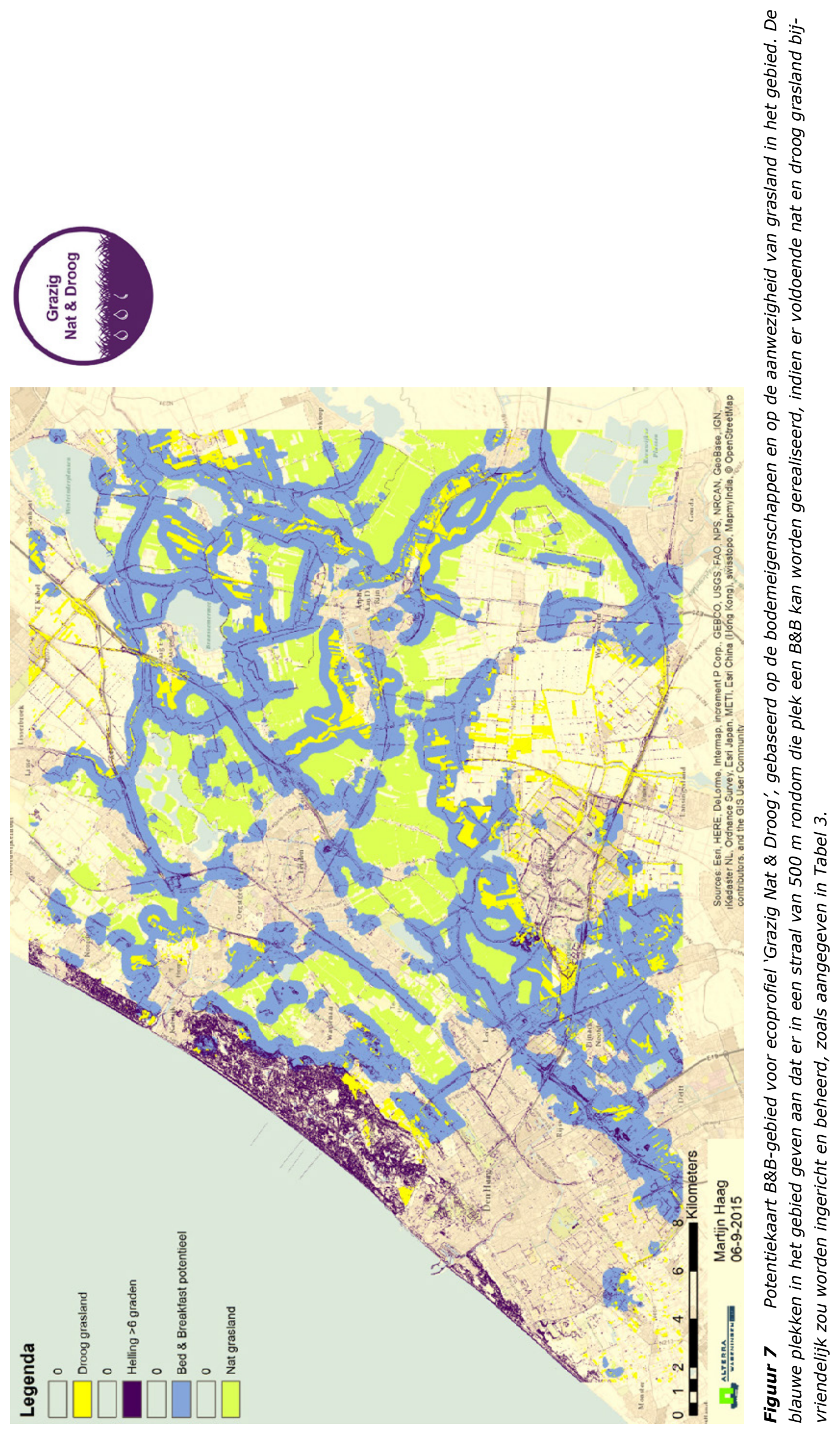




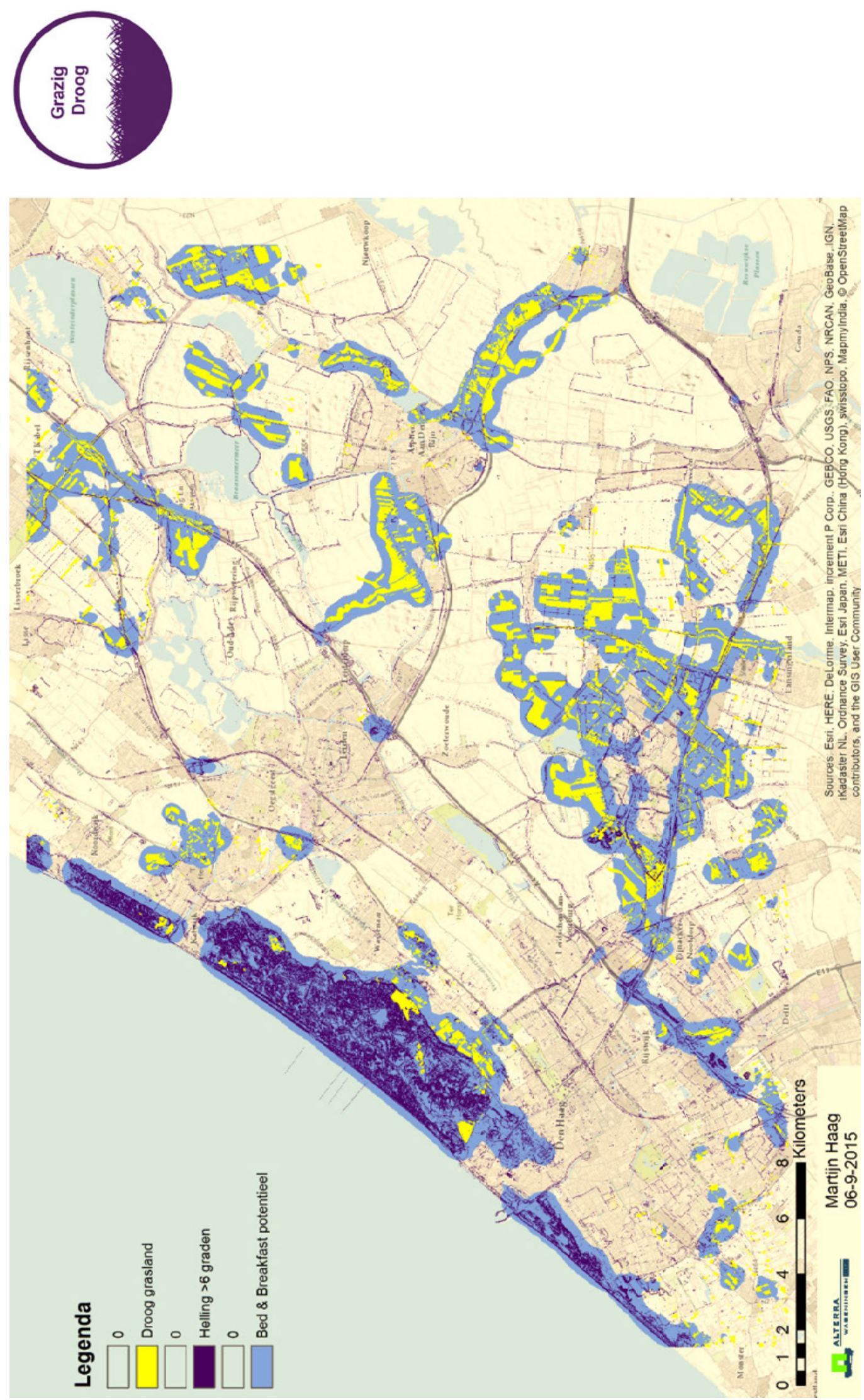

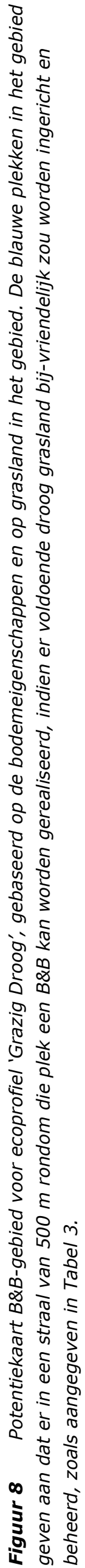



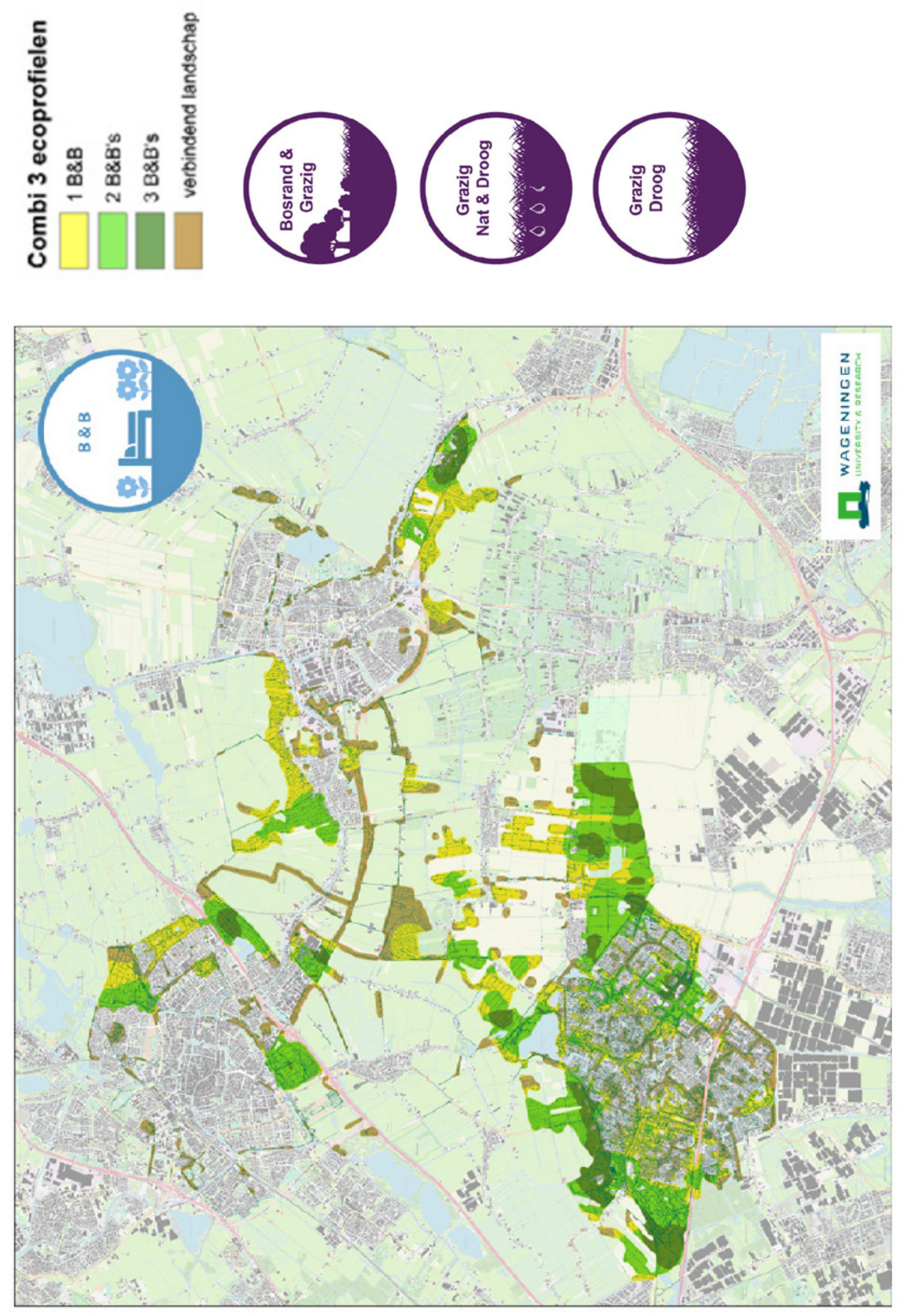

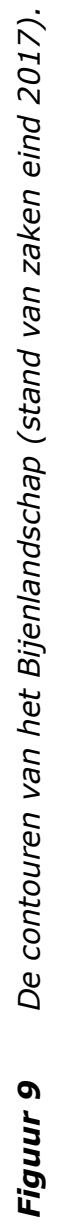




\subsection{Contouren van het Bijennetwerk}

De gebieden waar al activiteiten plaatsvinden of waar initiatieven worden genomen, zijn op de kaart gezet. Op die manier worden de contouren van een regionaal bijenlandschap zichtbaar. Onderstaande kaart laat ziet in welke gebieden initiatieven voor een bij-vriendelijker landschap het meest gewenst zijn, omdat ze het bijennetwerk het effectiefst kunnen versterken (Figuur 9).

\subsection{Bijkomende voordelen van het Bijennetwerk}

Een natuurlijke inrichting van een terrein levert meer op dan alleen bestuivende insecten, honing en een aantrekkelijk gebied. Ook andere soorten, zoals vogels, profiteren hiervan. Bomen en struiken helpen om de lucht te zuiveren en bieden beschutting tegen de wind. Bij-vriendelijke inrichting en beheer zijn ook goed te combineren met andere ingrepen in het landschap voor bijvoorbeeld waterbeheer. Natuurvriendelijke oevers bijvoorbeeld zuiveren het water, vergroten de capaciteit voor waterberging in de watergang en leveren leefgebied op voor bestuivende insecten.

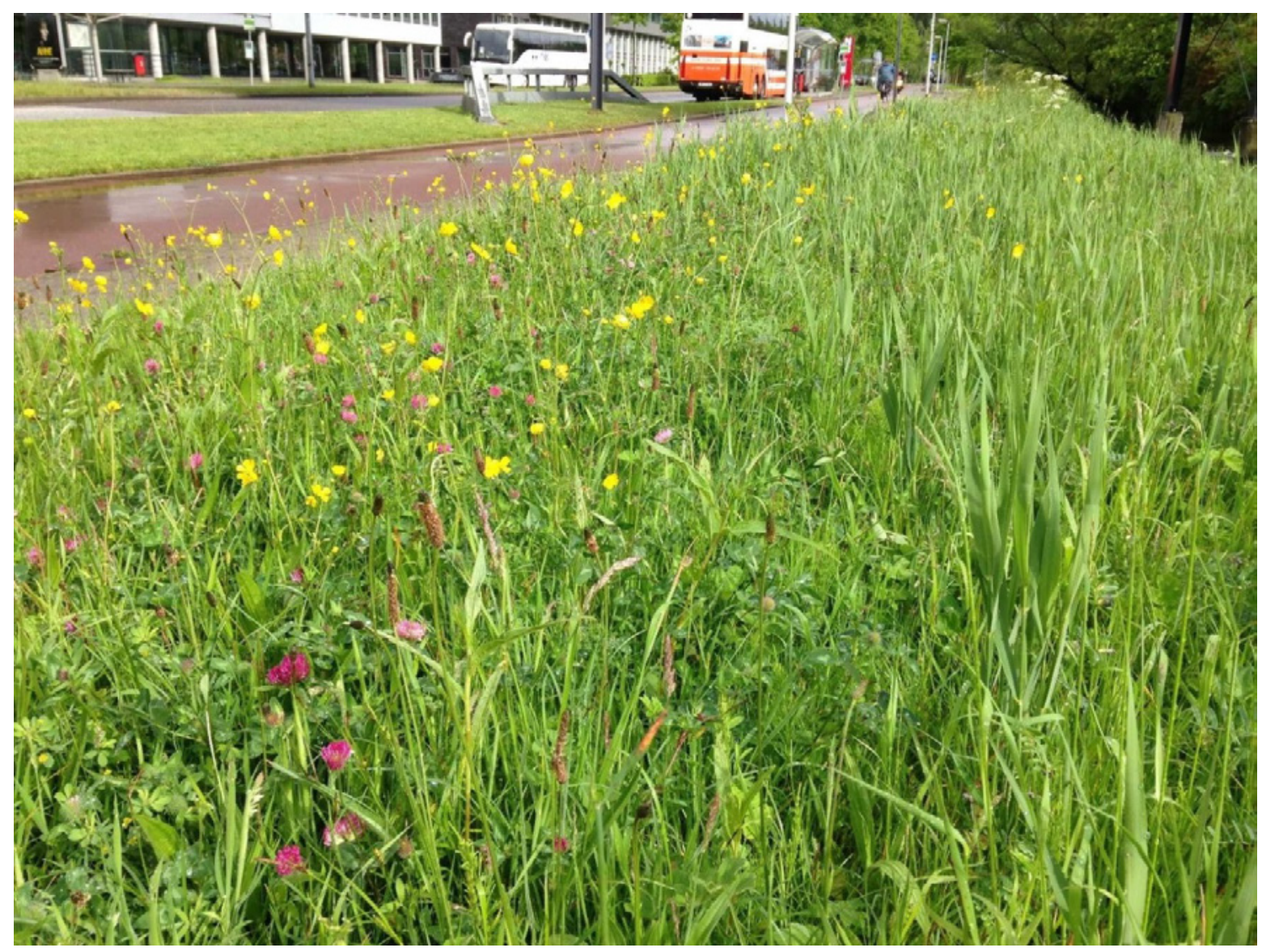

Bij-vriendelijke bermen zijn ook voor mensen aantrekkelijk (Foto: M. Reemer). 


\section{Wilde bijen en hommels}

De honingbij is bij iedereen bekend. Deze honing-producerende bij leeft in sociale volken en wordt door imkers gehouden in bijenkasten. Minder bekend zijn de meer dan 350 soorten wilde bijen die in Nederland voorkomen. Deze worden niet verzorgd door imkers en moeten zelf zorgen voor onderdak. Ook hommels behoren tot de wilde bijen. Wilde bijen nestelen op allerlei plekken. Veel soorten graven zelf hun nest in de bodem, met name op schaars begroeide plekken. Sommige hommels maken gebruik van verlaten muizenholen. Andere soorten nestelen in dood hout, waarin andere insecten gangen hebben uitgeknaagd. Ook zijn er diverse soorten die hun nesten in holle takjes en stengels bouwen, en zelfs enkele soorten die uitsluitend nestelen in lege slakkenhuisjes. Hoe meer variatie er in een terrein is aan zulke 'microstructuren', hoe meer bijensoorten er een geschikte nestelplek kunnen vinden. Bijen houden van warmte, dus een belangrijke voorwaarde voor een geschikte nestelplek is dat deze een flink deel van de dag in de zon moet liggen.

Alle bijen bezoeken bloemen. Zij drinken nectar voor hun eigen energievoorziening en verzamelen stuifmeel als voedsel voor de larven. Met dit stuifmeel vliegen ze naar hun nest, waar ze het in de nestcellen opbergen en er hun eieren op leggen. Veel soorten bijen zijn in bepaalde mate gespecialiseerd in hun bloembezoek. Gespecialiseerde bijen verzamelen bijvoorbeeld alleen stuifmeel op wilgen, boterbloemen, kattenstaart of klavers. Een bij vliegt dagelijks diverse malen op en neer tussen nest en bloemen om voldoende voedsel te verzamelen. Het is dus belangrijk dat geschikte nestelplaatsen niet te ver van de bloemen vandaan liggen.

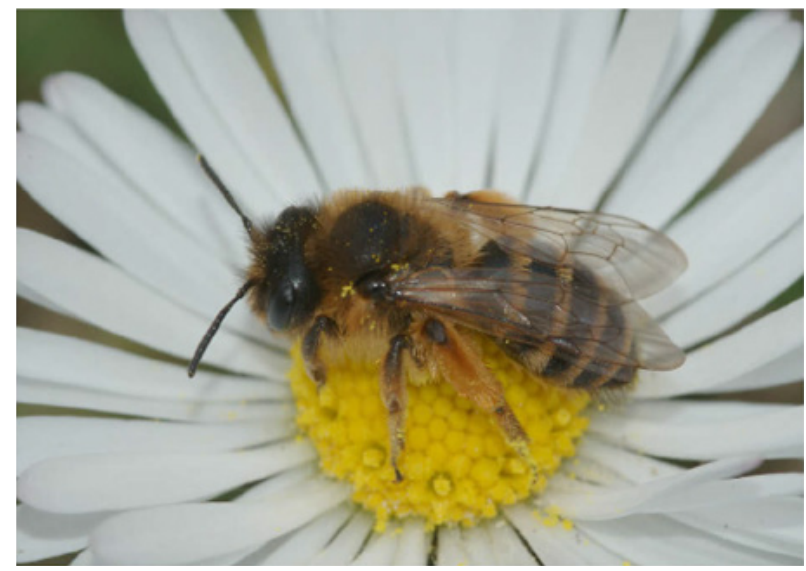

Grasbij (Foto: R. Kleukers).

\section{Zweefvliegen}

Zweefvliegen kunnen als kleine helikoptertjes stilstaan in de lucht. Veel soorten lijken in uiterlijk op bijen, hommels of wespen, maar steken kunnen ze niet. Zweefvliegen hebben met bijen gemeen dat ze vaak bloemen bezoeken. In tegenstelling tot bijen gebruiken zweefvliegen nectar en stuifmeel echter alleen als voedsel voor de volwassen vliegen, niet voor hun larven.

Juist in de voedingsgewoonten van de larven verschillen de 330 Nederlandse soorten zweefvliegen sterk van elkaar. De voedselkeuze van de larven bepaalt in grote mate waar een zweefvlieg voorkomt. Grofweg zijn er vier ecologische hoofdgroepen te onderscheiden:

Bladluiseters - Deze lopen over kruiden, bomen en struiken en voeden zich met bladluizen. Net als lieveheersbeestjes zijn deze zweefvliegenlarven belangrijke biologische bestrijders van bladluizen. Sommige soorten hebben een breed dieet van uiteenlopende soorten bladluizen, andere zijn kieskeuriger.

Planteneters - Deze leven in wortels, stengels en bladeren van planten. Deze soorten zijn sterk gespecialiseerd in bepaalden plantensoorten. Zo zijn er soorten die in fluitenkruid leven, in koninginnenkruid of in distels.

Water- en modderbewoners - Deze larven voeden zich met bacteriën in nat, rottend materiaal, zoals in de modder langs oevers. Sommige soorten leven in voedselrijke omstandigheden, terwijl andere juist schoon en minder voedselrijk water prefereren. Ze halen adem door een lange, telescopisch uitschuifbare buis aan het uiteinde van hun achterlijf.

Houtmolmbewoners - Net als de water- en modderbewoners voeden deze larven zich met bacteriën, alleen doen houtmolmbewoners dit op allerlei plekjes die met dood hout en oude bomen te maken hebben. Enkele soorten boren zich een weg door dood, rottend hout, andere leven in natte boomholten of in sap dat uit beschadigde boombast vloeit. 


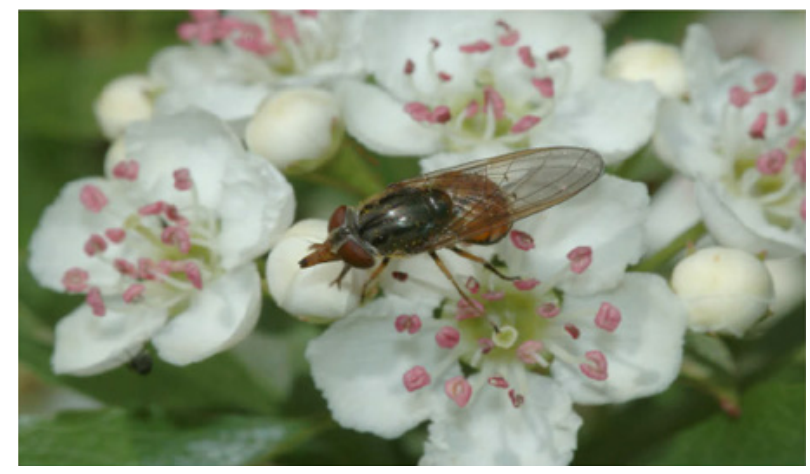

Gewone Snuitvlieg, in het Engels 'Heinekenvlieg' genoemd (Foto: R. Kleukers).

\section{Vlinders}

Vlinders zijn vrolijke fladderaars met mooie kleuren. Maar het vlinderleven begint als eitje, waaruit een rups tevoorschijn komt. Het vlindervrouwtje is bij het leggen van haar eitjes vaak kieskeurig: ze kiest alleen planten uit die voldoen aan haar eisen. Elke vlindersoort legt eitjes op één of meerdere plantensoorten. Dit wordt ook wel de waardplant genoemd. Het is de plant waar de rups van eet en groot van wordt. Denk bijvoorbeeld aan de Kleine vos, die Brandnetel als waardplant heeft. De rups verpopt na een tijdje en uit de pop komt een nieuwe vlinder tevoorschijn. Het vlinderleven duurt maar kort, meestal één tot enkele weken.

Er leven in Nederland 71 soorten dagvlinders. Daarvan heeft ruim 30\% een status 'bedreigd' op de Rode Lijst. Als volwassen individu leven vlinders van nectar uit bloemen. Ze kunnen daarom met eenvoudige maatregelen als het bloemrijk maken van tuin of grasland geholpen worden. Aanplant van waardplanten helpt eveneens.

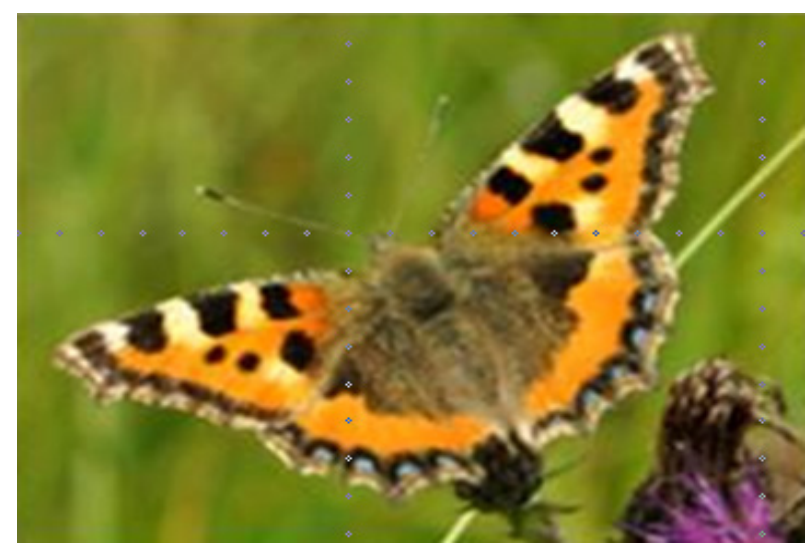

Kleine Vos (Foto: De Vlinderstichting). 


\section{Hoe maak ik mijn terrein bij-vriendelijk?}

\subsection{Bij-vriendelijk beheer}

Met onderstaande beheermaatregelen kunt u uw terrein geschikter maken voor bijen en andere bestuivende insecten.

\section{Maaien met beleid}

Maaien is in gras- en rietlanden de aangewezen methode om het gebied geschikt voor bijen te maken of te houden. Mits dit tenminste goed gebeurt, want met maaien kan veel mis gaan. De volgende zaken zijn van belang. De kosten van bij-vriendelijk maaibeheer zijn uiteindelijk iets lager dan van regulier gazonbeheer.

- Maai altijd gefaseerd. Voor elke maaibeurt, ongeacht wanneer deze plaatsvindt, geldt: maai gefaseerd. Dit betekent dat een deel van de vegetatie niet gemaaid wordt. Afhankelijk van het terrein en de mogelijkheden, bedraagt het ongemaaide deel 15-30\% van de oppervlakte (dit hoeft geen aaneengesloten oppervlakte te zijn; het mogen ook verschillende snippers verdeeld over het terrein zijn). Dit zorgt er voor dat er ook na een maaibeurt nog voedsel te vinden is. Ook in de winter dient een deel ongemaaid te blijven, zodat soorten die in de vegetatie overwinteren (bijvoorbeeld in holle stengels), kunnen overleven. Ook in rietvelden is dit belangrijk, omdat vele dieren, waaronder sommige bijen, zich in overjarige rietstengels ontwikkelen. Door het in de winter overstaande deel elke drie jaar te wisselen, kan dichtgroei of te sterke verruiging voorkomen worden.

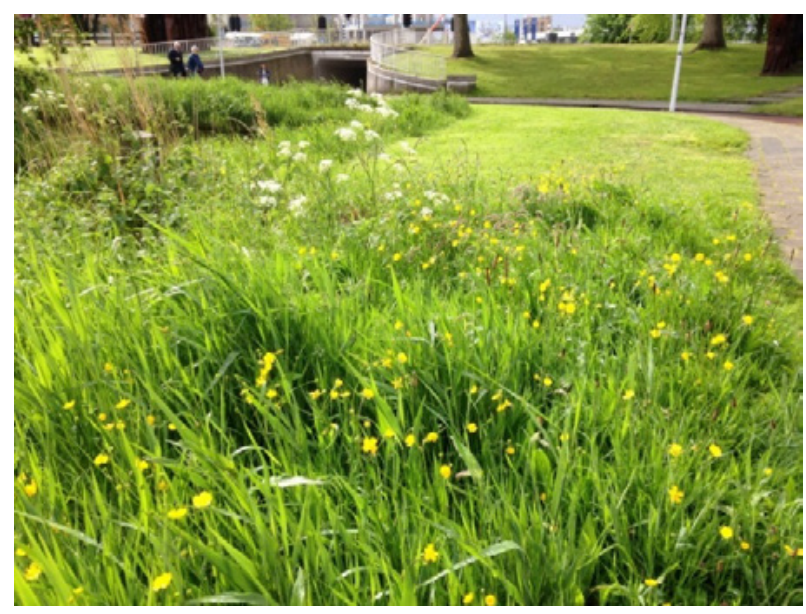

Gefaseerd maaien (Foto: M. Reemer).

- Maai één of twee keer per jaar. Bij vaker maaien zijn er te veel onderbrekingen in de voedselvoorziening, waardoor bijen hun nesten niet van voldoende voedsel kunnen voorzien. Probeer bij het vaststellen van de maaidata rekening te houden met het moment waarop belangrijke planten in de vegetatie hun zaad hebben afgezet. Dit moment kan van jaar tot jaar verschillen, afhankelijk van de weersontwikkelingen (zie ook kader 'Borgen van bij-vriendelijk maaibeheer in Leiderdorp').

- Zorg voor een zo schraal mogelijke bodem. Verschralen van graslanden kan nodig zijn in zeer voedselrijke situaties, waar enkele plantensoorten zo dominant zijn dat een bloemrijke vegetatie geen kans krijgt. In zo'n geval kan van bovenstaande richtlijnen afgeweken worden door driemaal per jaar volledig te maaien, het maaisel af te voeren en dit beheer drie jaar vol te houden, alvorens over te gaan op het hierboven omschreven beheer. Eventueel kan overwogen worden om de voedselrijke toplaag eerst af te graven (20 à $30 \mathrm{~cm}$ ). 
- Maai in het najaar. Bijen hebben voedsel nodig van het vroege voorjaar tot de nazomer. Maai daarom bij voorkeur pas in september, wanneer de meeste bijen hun levenscyclus voltooid hebben. Zorg er wel voor dat (een deel van) de vegetatie ongemaaid de winter ingaat (zie volgende punt). Maaien in het voorjaar of midden in de zomer is schadelijk voor veel bijen. Wanneer dit om bepaalde redenen toch wenselijk is, maai dan gefaseerd (zie boven).

- Voer het maaisel af. Door het maaisel kort na de maaibeurt af te voeren (hooien), voorkomt u dat voedingsstoffen aan de bodem worden toegevoegd. De bodem krijgt hierdoor de kans om te verschralen, wat een gunstig effect heeft op de bloemenrijkdom.

- Gebruik licht materieel. Zware machines drukken de bodem samen, waardoor grondnesten verloren kunnen gaan.

- Niet klepelen. Klepelen is een vorm van maaien waarbij de vegetatie min of meer wordt stukgeslagen en al het maaisel blijft liggen. Dit zorgt voor verrijking van de bodem, waardoor de vegetatie sterk verruigt en dichtgroeit. Een beperkt aantal grassen, brandnetels of zuring wordt vaak dominant en dit gaat ten koste van de bloemenrijkdom en dus van de bijen.

\section{Snoeien na de bloei}

Snoei heesters en hagen ná de bloei. Wanneer ze voor de bloei gesnoeid worden, leveren ze geen voedsel voor bijen, hommels en zweefvliegen.

\section{Begrazing: met mate}

Begrazing is voor bijen al gauw te veel. Grazend vee houdt namelijk van dezelfde bloemen als bijen (klavers, wikke, ratelaars, paardenbloemen, streepzaad), met als gevolg dat er in een volledig begraasd terrein vaak maar weinig bloemen te vinden zijn. Dit geldt niet voor planten die het vee ongemoeid laat, zoals boterbloemen, maar dit zijn uitzonderingen waar relatief weinig bijensoorten van profiteren.

Toch kunnen er met extensieve begrazing goede resultaten bereikt worden, bijvoorbeeld in combinatie met hooibeheer. Ook kan gedacht worden aan het kortstondig inzetten van grazers in een beperkt deel van het terrein. Dit heeft weliswaar een onderbreking in de bloei tot gevolg, maar het stimuleert ook een tweede bloei, doordat de afgegraasde bloemen snel nieuwe bloemen gaan ontwikkelen en het kan de variatie in vegetatiestructuur vergroten.

\section{Inzaaien}

Inzaaien is een manier om plantensoorten in de vegetatie (terug) te krijgen in gebieden waar weinig natuurlijke zaadbronnen in de omgeving aanwezig zijn of om in korte tijd een bloemrijke eenjarige vegetatie te ontwikkelen (bijvoorbeeld op braakliggende terreinen). Stem het beheer na inzaaien af op het stimuleren van een bloem- en insectenrijke vegetatie. Het is niet zo dat er na een keer inzaaien niets meer hoeft te gebeuren; dan is het binnen twee jaar weer over met de bloemenrijkdom. Let bij het uitkiezen of samenstellen van het zaadmengsel op de volgende zaken:

- Kies bloemen die voor bijen aantrekkelijk zijn. Vooral zaadmengsels met veel lip- en vlinderbloemen komen hiervoor in aanmerking. (Zie de volgende paragraaf voor voorbeelden.)

- Zorg voor variatie in bloeitijd. Sommige bloemen bloeien vroeg in het jaar, andere laat. Houd hier rekening mee (zie voor meer informatie www.drachtplanten.nl).

- Kies bloemen die in het gebied ook van nature voorkomen. Dit verhoogt de kans dat de bloemen daadwerkelijk door veel verschillende soorten bijen bezocht gaan worden. Een manier om op natuurlijke wijze de ontwikkeling van bloemrijk grasland te stimuleren, is het uitstrooien van maaisel of plagsel afkomstig van een ander bloemrijk hooiland. Gebruik hiervoor bij voorkeur 'streekeigen' maaisel of plagsel uit een nabij gelegen gebied met vergelijkbare bodemsamenstelling en vochthuishouding. Dit vergroot de kans van slagen.

- Kies ook bloemen die twee- of meerjarig zijn. Mengsels met uitsluitend eenjarige bloemen (zoals de populaire klaprozen) moeten vaak ieder jaar opnieuw ingezaaid worden. Mengsels met meerjarige bloemen gaan langer mee, maar hebben wel goed beheer nodig (maaien en maaisel afvoeren), anders nemen grassen het in veel gevallen over en moet er opnieuw ingezaaid worden.

- Let op voedselrijkdom en vochtigheid van de bodem. Bepaalde soorten doen het op bepaalde bodems heel goed, maar op andere juist niet. Het voert te ver om dit hier toe te lichten, maar meer hierover is bijvoorbeeld te lezen op www.drachtplanten.nl en in het Plantenvademecum voor tuin, park en landschap (Koster 2007; zie literatuurlijst achter in deze handreiking). 
- Zorg ervoor dat het zaaigoed niet behandeld is met een laagje 'gewasbeschermingsmiddelen'. Deze middelen komen ook in het stuifmeel en de nectar van de plant terecht en zijn schadelijk voor bijen. Gebruik dus ecologisch geteeld zaad, zoals dat verkrijgbaar is bij gespecialiseerde zaadhandels.

\section{Beheer van bos en struweel}

- Koester wilgen, sleedoorn, meidoorn, lijsterbes, vogelkers en braamstruweel. Deze vormen belangrijke voedselbronnen, met name in het voorjaar. Vooral grauwe wilg, geoorde wilg en boswilg kunnen met hun massale voorjaarsbloei vele bijen aantrekken. Braamstruweel bloeit later in het jaar en dode stengels bieden nestgelegenheid aan onder andere maskerbijen.

- Zorg voor een mix van vroeg- en laatbloeiende soorten. Er is dan voor bijen en andere insecten gedurende het grootste deel van het jaar voedsel te vinden. Vroege bloeiers zijn diverse wilgensoorten en sleedoorn (zie boven), gele kornoelje en Spaanse aak. In het voorjaar en de vroege zomer bloeien meidoorn, zoete kers, linde en fruitbomen. Late bloeiers zijn braam en klimop. Stem de beplantingskeuze altijd af met het bodemtype en lokale (grond)waterstand. Dit is in hoge mate bepalend voor het 'aanslaan' van de beplanting.

- Creëer geleidelijke bosranden. Veel bosranden hebben een abrupte overgang: er is een strakke grens tussen korte vegetatie en bos. Een geleidelijke overgang van lage naar hoge vegetatie via struweel levert echter meer variatie in leefgebieden voor bijen en zweefvliegen op. Geleidelijke bosranden kunnen op twee manieren gecreëerd worden. De eerste is het kappen van de buitenste een à twee rijen bomen. Hierbij geen volledige rijen verwijderen, maar variëren, zodat een kleinschalig gevarieerde bosrand ontstaat. Verwijder liever geen grote, oude bomen (zie onder). De tweede manier is door struweel langs de bestaande bosrand zich op natuurlijke wijze te laten ontwikkelen. Het is handig om de rand dan af te rasteren, zodat het zich ontwikkelende struweel niet ten prooi valt aan gretige grazers of onoplettende maaiers.

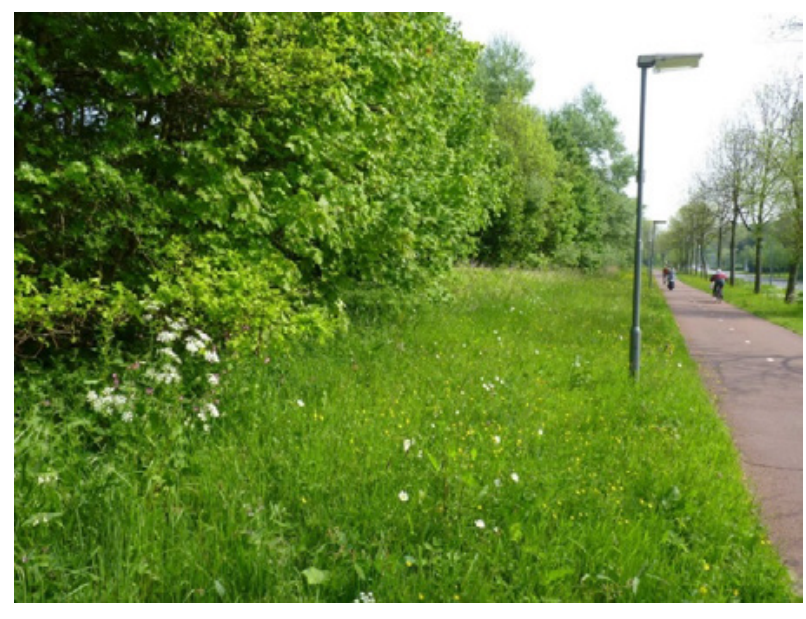

Voorbeeld van een geleidelijke overgang tussen gras en bos (Foto: M. Reemer).

- Creëer inhammen. Zowel langs bosranden als langs paden kunnen open plekken (van bijvoorbeeld $25 \times 50$ meter) gecreëerd worden waar bloemrijke vegetaties en nestplekken kunnen ontstaan. Vooral langs oost-west lopende randen en paden kan dit aantrekkelijke, snel opwarmende plekjes opleveren. Verwijder liever geen grote, oude bomen (zie onder).

- Laat oude, zieke en dode bomen ongemoeid. Oude, zieke en dode bomen bieden op diverse wijze geschikt leefgebied voor bijen en zweefvliegen. In droge boomholten kunnen boomhommels nestelen, in natte boomholten leven larven van zweefvliegen. Zieke en dode bomen herbergen vele zweefvliegenlarven in rottende molm en uitvloeiend sap. Ook ondergrondse stronken en wortels zijn geschikt voor bepaalde soorten. Dode bomen in de zon bieden nestelgelegenheid aan vele bijen, vooral wanneer keverlarven in deze stronken gangen hebben uitgeknaagd. Vooral staand dood hout is belangrijk als nestelplaats.

Bij het aanbesteden van groenbeheer gericht op het stimuleren van de bijenfauna is het aan te raden om dit te doen bij ecologische hoveniers of hoveniers met affiniteit met bij-vriendelijk groenbeheer. 
Vakvereniging De Wilde Weelde is een overkoepelende organisatie voor een groot aantal bedrijven van natuurvriendelijke hoveniers, kwekers en leveranciers van zaden en planten.

\subsection{Bij-vriendelijke inrichting}

\section{Aanplanten}

- Gebruik inheemse struiken en bomen. Dit verhoogt de kans dat de bloemen daadwerkelijk door veel verschillende soorten bijen bezocht gaan worden. Goede bomen voor wilde bijen zijn onder andere wilgen (boswilg, geoorde wilg, grauwe wilg), meidoorn, sleedoorn, lijsterbes, appel, pruim, (vogel)kersen. Ook wel geschikt zijn esdoorns en linden.

- Gebruik onbespoten planten en bloembollen. Pesticiden en insecticiden zijn vaak ook lang na de behandeling nog in de plant aanwezig en worden via nectar en stuifmeel op de bijen overgedragen.

- Let op voedselrijkdom en vochtigheid van de bodem. Niet alle plantensoorten gedijen op alle bodemtypen (zie Tabel 5). Voor meer informatie zie www.drachtplanten.nl.

- Denk aan waardplanten voor vlinders. Hierop leggen de vlinders hun eitjes en leven de rupsen. Zo leeft de Citroenvlinder op Sporkehout, het Oranjetipje op Pinksterbloem en Look-zonder-look en het Boomblauwtje op klimop en Grote kattenstaart (zie www.vlinderstichting.nl/lijst-van-waardplanten).

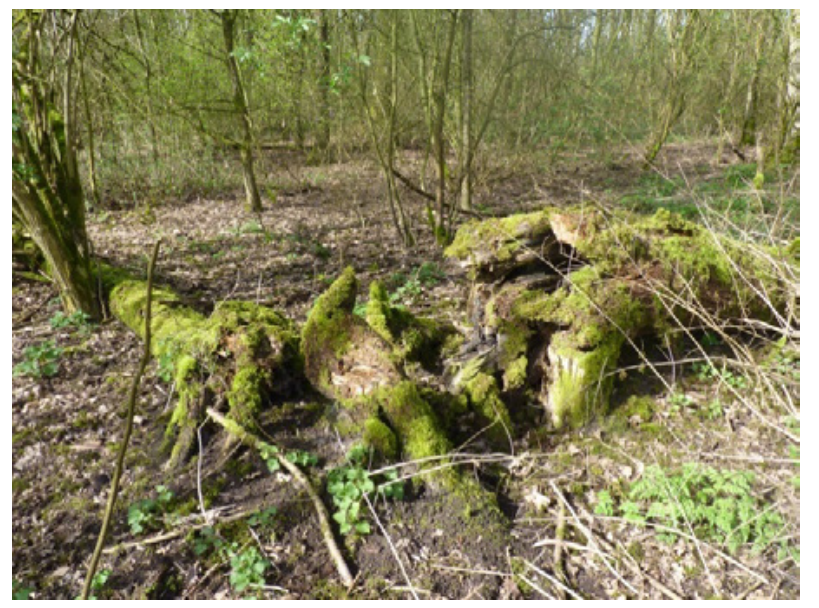

Dood hout, liefst in de zon, biedt nestelgelegenheid voor veel bijen en zweefvliegen(Foto: M. Reemer). 
Tabel $5 \quad$ Voorbeelden van voor bijen aantrekkelijke planten die in het Land van Wijk en Wouden voorkomen en de vochtigheid van de bodem van hun standplaats.

\begin{tabular}{|c|c|c|}
\hline Plantensoort & Droge bodem & Natte/vochtige bodem \\
\hline boerenwormkruid & $x$ & \\
\hline duizendblad & $x$ & \\
\hline fluitenkruid & $x$ & \\
\hline gewone ereprijs & $x$ & \\
\hline groot streepzaad & $x$ & \\
\hline grote kattenstaart & & $x$ \\
\hline grote ratelaar & $x$ & \\
\hline grote wederik & & $x$ \\
\hline moerasandoorn & & $x$ \\
\hline moerasrolklaver & & $x$ \\
\hline peen & $x$ & \\
\hline rode klaver & $x$ & \\
\hline scherpe boterbloem & $x$ & \\
\hline smeerwortel & $x$ & $x$ \\
\hline veldlathyrus & $x$ & \\
\hline vingerhoedskruid & $x$ & \\
\hline vogelwikke & $x$ & \\
\hline
\end{tabular}

\section{Creëer kleinschaligheid}

Kleinschalige inrichting en beheer is gunstig voor bijen. Grote, eenvormige oppervlakten bieden weinig diversiteit aan leefgebieden, waardoor maar weinig bijensoorten zich er thuis voelen. Zorg dus voor veel variatie in vegetatiestructuur: laag en hoog, dicht en open, met hier en daar kale plekjes.

Hoogteverschillen in een terrein zorgen voor allerlei nestplekken en voor gradiënten in bijvoorbeeld bodemvochtigheid. Voorbeelden zijn greppeltjes, zand- en houtwallen, kuilen en heuveltjes. Ook dood hout en oude weidepaaltjes (niet met teer bewerkt) bieden geschikte nestplekken voor sommige soorten. In een kleinschalig terrein liggen bovendien nestelplekken en foerageerplekken vaak dicht bij elkaar. Door een dergelijke kleinschalige variatie in een terrein te stimuleren, zal de bijendiversiteit toenemen.

\section{Bovengronds bijenhotels}

Diverse bijensoorten bouwen hun nesten in door kevers geknaagde gangen in dood hout of in holle stengels van onder andere riet, vlier en braam. Dergelijke nestplekken kunnen makkelijk worden nagebootst om zo het nestelen van bijen in een gebied te stimuleren. Door gaten te boren in stukken hout en door holle stengels te bundelen en deze op een zonnige plek te hangen, kunnen verschillende bijensoorten getrokken worden. Kijk voor meer informatie op www.bestuivers.nl/bijenhotels. Let bij het bouwen, plaatsen en onderhouden van bijenhotels op de volgende zaken.

- Varieer de diameter van de gaten en stengels tussen de 3 en $8 \mathrm{~mm}$. Kleinere of grotere gaten trekken nauwelijks bijen. De lengte van de gang maakt niet zo veel uit, maar: hoe dieper, hoe meer nestcellen de bijen kunnen aanleggen.

- De boorgangen of stengels moeten aan één kant dicht zijn. Bij het boren niet tot aan de andere kant van het hout boren. Bij gebruik van stengels fungeren de 'knopen' in bijvoorbeeld bamboestengels als natuurlijke afsluiting. Open stengels kunnen afgesloten worden met bijvoorbeeld klei of een wattenpropje.

- Gebruik hard hout, zoals eiken, esdoorn, es of beuk. Zacht hout, zoals van wilg, heeft als nadeel dat de gangen niet glad zijn van binnen. Bijen houden daar niet van. Steen of beton is ook niet erg aantrekkelijk voor bijen. 
- Gebruik verschillende stengels, zoals van bamboe, riet, vlier, braam of Japanse duizendnoop. Sommige stengels gaan vrij snel scheuren en zijn dan aan vervanging toe. Sommige internetwinkels verkopen speciale kartonnen kokertjes voor bijenhotels. Deze werken prima, al hebben ze vaak maar één diameter, zodat ze een beperkt aantal soorten aantrekken. Kunststof is minder geschikt, omdat de inhoud hierin snel gaat schimmelen.

- Boor dwars op de naden van het hout, niet met de naden mee. Zo ontstaan er minder snel scheuren in de gangen; gescheurde gangen zijn ongeschikt voor bijen. Vaak worden schijven van boomstammen gebruikt voor bijenhotels, maar deze scheuren snel omdat er met de naden mee geboord wordt.

- Plaats het bijenhotel op een zonnige plek. Bijenhotels op het noorden of onder de bomen worden niet door bijen gebruikt.

- Zorg voor een afdakje tegen instromend regenwater.

- Vervang op tijd de nestblokken of stengels. Na een jaar of twee worden veel bijenhotels minder geschikt vanwege scheuren, schimmelvorming en dergelijke. Om vervanging makkelijk te maken, is het aan te bevelen om met een systeem van uitneembare delen te werken. Zulke delen kunnen bestaan uit houten cassettes, lege conservenblikken e.d.

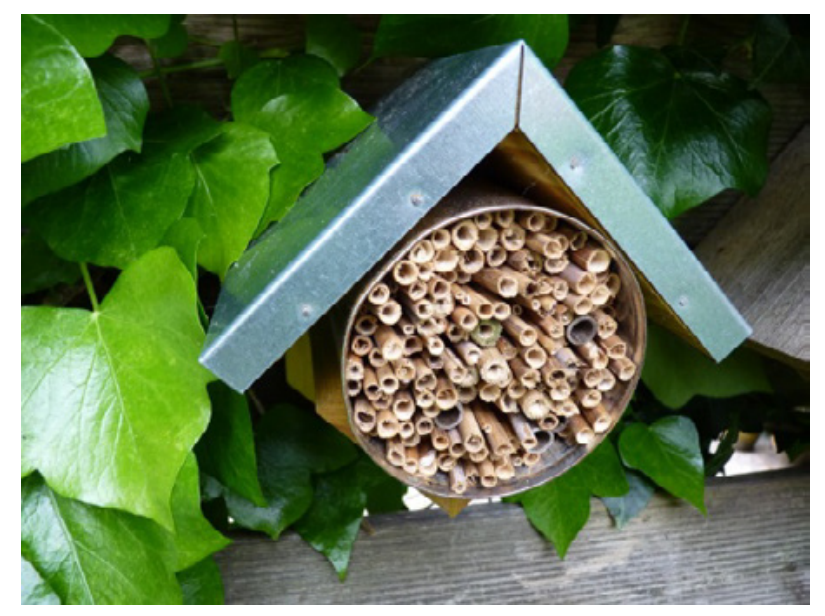

Klein bijenhotel (Foto: M. Reemer).

\section{Ondergrondse bijenhotels}

Ook ondergronds nestelende soorten kunnen geholpen worden met kunstmatig aangelegde nestelgelegenheid. Het verdient hierbij aanbeveling om met leem of leemhoudend zand te werken, zeker niet met zware klei of donker, humeus zand. Licht zand werkt ook wel. Met zulk leem of zand kunnen bijvoorbeeld dijkjes worden aangelegd. Van groot belang is dat een van de zijden van een dergelijk dijkje door de zon beschenen wordt. Ook kan leem of leemhoudend zand worden aangebracht in bakken of blikken die in een bijenhotel worden geplaatst. Door hier kleine, ondiepe gaatjes in aan te brengen, zullen bijen hier sneller in gaan nestelen. Dit verschaft ze alvast een beginnetje, de rest van de gang knagen en graven ze zelf uit. 


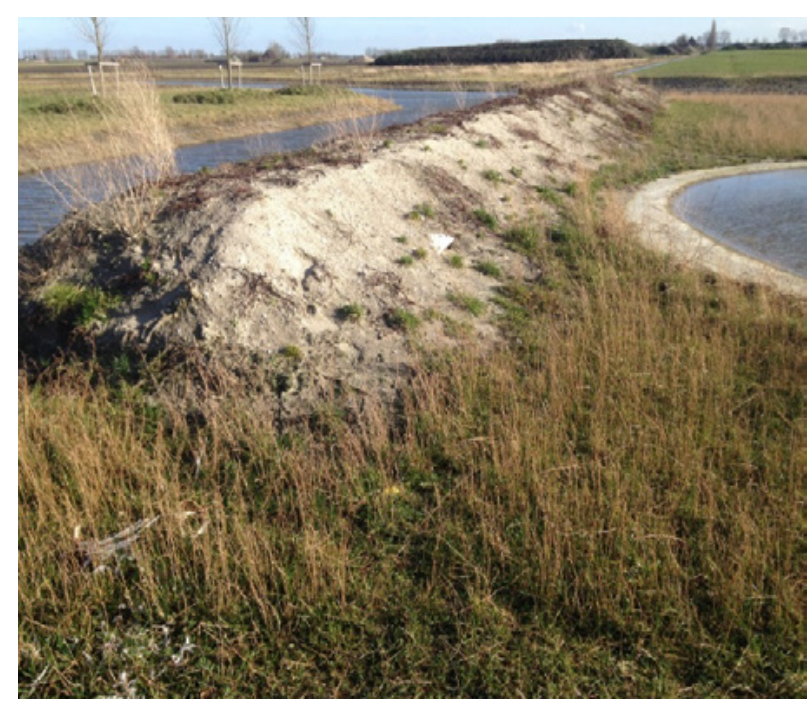

Nesteldijkje (Foto: M. Reemer).

\section{Honingbijenkasten}

Het is leuk om door het plaatsen van bijenkasten honing te kunnen oogsten van uw eigen terrein, en het leven van deze honingbijen van dichtbij te kunnen volgen. Wanneer er niet te veel bijenkasten worden geplaatst kunnen honingbijen en wilde bijen prima naast elkaar in een gebied voorkomen. Bij een maximum van drie bijenkasten per vierkante kilometer/per bed \& breakfast, beconcurreren ze elkaar niet te sterk. In een gebied met veel (mannelijke) wilgen die veel stuifmeel leveren, kunnen dit er eventueel meer zijn. Lees meer over concurrentie tussen honingbijen en wilde bijen op www. bestuivers. $\mathrm{nl} /$ bedreiging/concurrentie-honingbij.

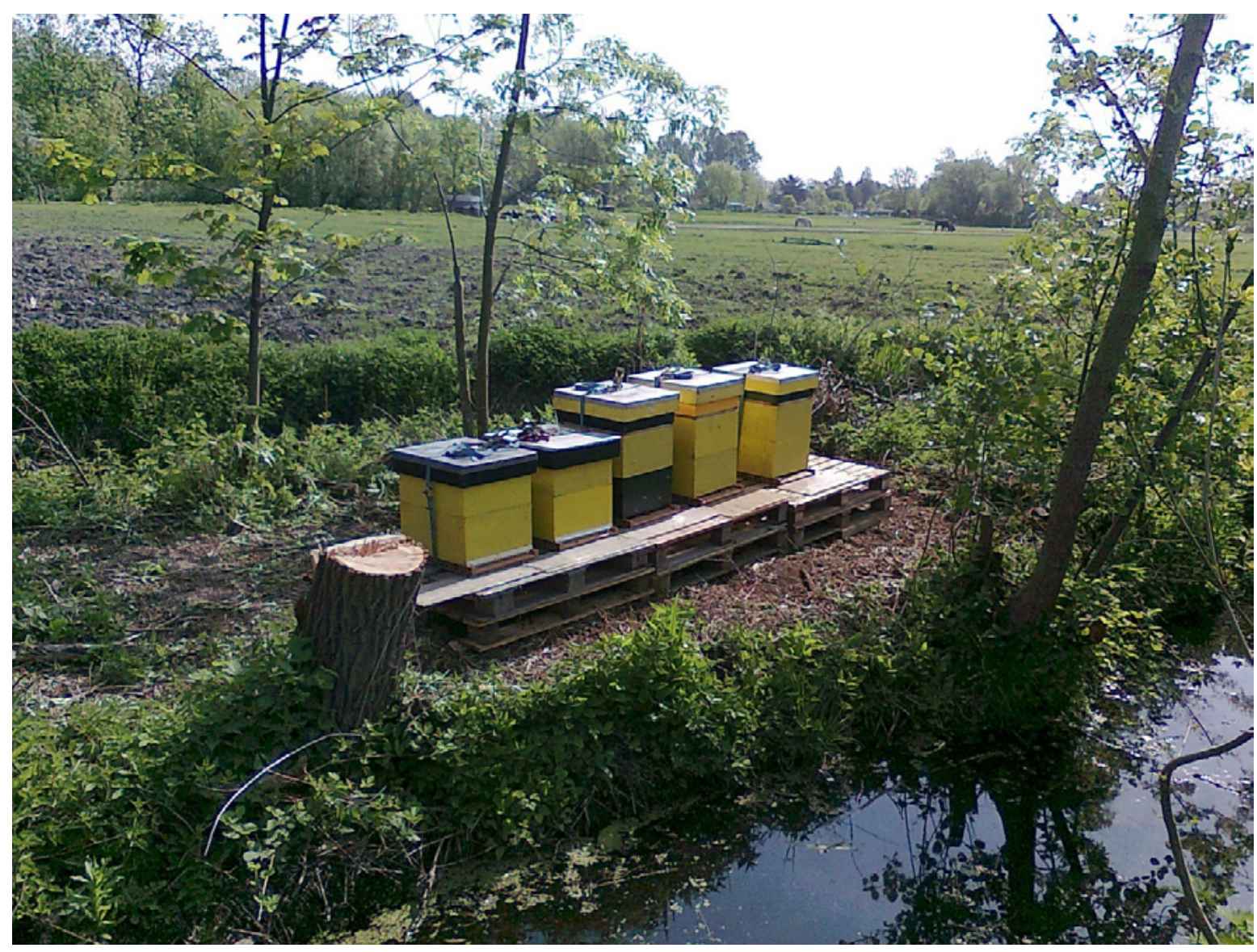

Bijenkasten (Foto: Stichting de Bijkerij). 


\section{$4 \quad$ Aandachtspunten voor specifieke terreintypen}

Hieronder worden aandachtpunten besproken voor een bij-vriendelijke inrichting en beheer van vier typen terreinen die in het Land van Wijk en Wouden een belangrijk onderdeel kunnen vormen van het regionale bijennetwerk: bedrijventerreinen, gemeentelijk groen, bermen en oevers en agrarisch gebied.

\subsection{Bedrijventerreinen}

Deze terreinen bieden het voordeel van hun ligging (vaak tussen stad en buitengebied) en zijn door de aanwezigheid van gebouwen windluw. Het bedrijfsgroen is doorgaans intensief onderhouden, de uitstraling is belangrijk (decoratieve bomen en struiken) en ecologische waarde is vaak geen aandachtspunt. Deze terreinen bieden allerlei mogelijkheden om bij-vriendelijker te worden en zelfs als Bed \& Breakfast-gebied of verbindingszone met stapsteen te fungeren indien bedrijven hun krachten bundelen:

- Werk kleinschalig: meer afwisseling in beplanting en beheer betekent mogelijkheden voor meer soorten.

- Vorm gazons en grasbermen om naar bloemrijk grasland met minder maaien.

- Vorm heestervakken om naar heesters of planten die meer voedsel bieden. Zorg wel voor bloei, dus zo nodig later snoeien.

- Beplant vaste plantborders met voedselplanten, met name de zonbeschenen ingangen van bedrijven en plekken rondom parkeerplaatsen bieden goede mogelijkheden.

- Plaats bijenhotels op zonnige, zichtbare plaatsen (bijv. op wand gebouw naast looproute).

- Zorg hier en daar voor een paar vierkante meters open, droge grond in zonbeschenen deel van het groen. Dit kunt u bijvoorbeeld doen door kleine heuveltjes of dijkjes te creëren van klei of zand.

- Koester braakliggende grond, de spontane vegetatie heeft veel te bieden aan bestuivende insecten.

- Laat bomen en struiken in bloei komen. Soms worden meidoornhagen bijvoorbeeld al voor de bloei gesnoeid. Dan komen er dat jaar geen bloemen meer aan.

- Gebruik geen gif bij het beheer (geldt zowel bij onkruid, ziektes als plagen bestrijden)!

- Gebruik zo veel mogelijk nectar- en stuifmeelrijke planten. Veel sierplanten produceren geen nectar of stuifmeel (meer). Hoe fraai ze er ook uit zien, bijen kunnen er geen voedsel uit halen.

- Beplant eventueel ook muren en daken. Daken kunnen worden vergroend met sedum of kruidachtige planten.

- Mocht u op uw eigen terrein te weinig ruimte hebben om een Bed \& Breakfast te kunnen herbergen, kijk dan over de grenzen van uw eigen terrein: ook de bermen die hierop aansluiten, kunnen onderdeel worden van het Bed \& Breakfast, of het terrein van uw buren. $U$ kunt met hen in gesprek gaan en hen meenemen in uw ambitie, en samen een Bed \& Breakfast-bouwsteen organiseren voor het Bijenlandschap. 

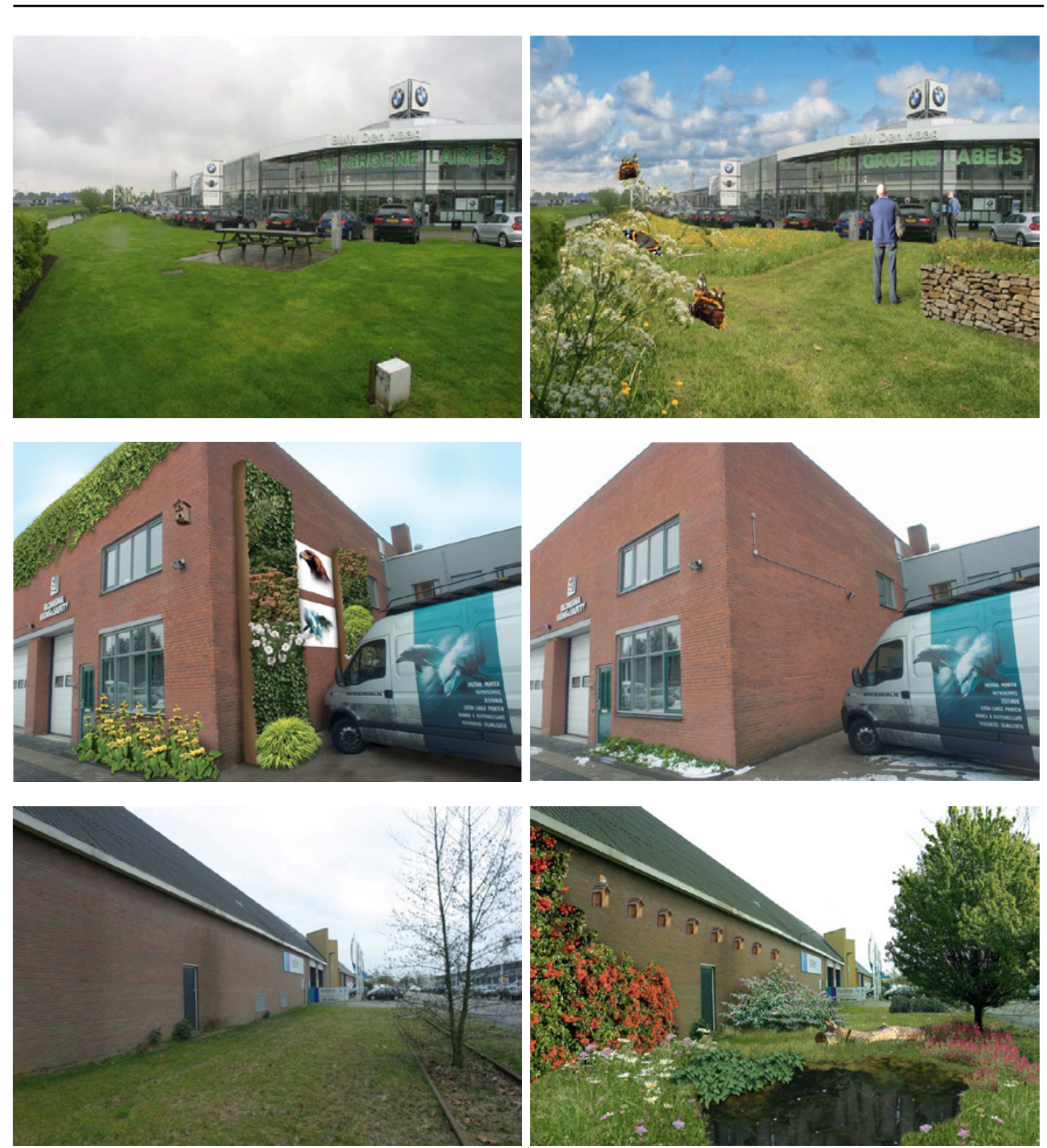

(Bron: Foto's en bewerkingen: R. Snep). 

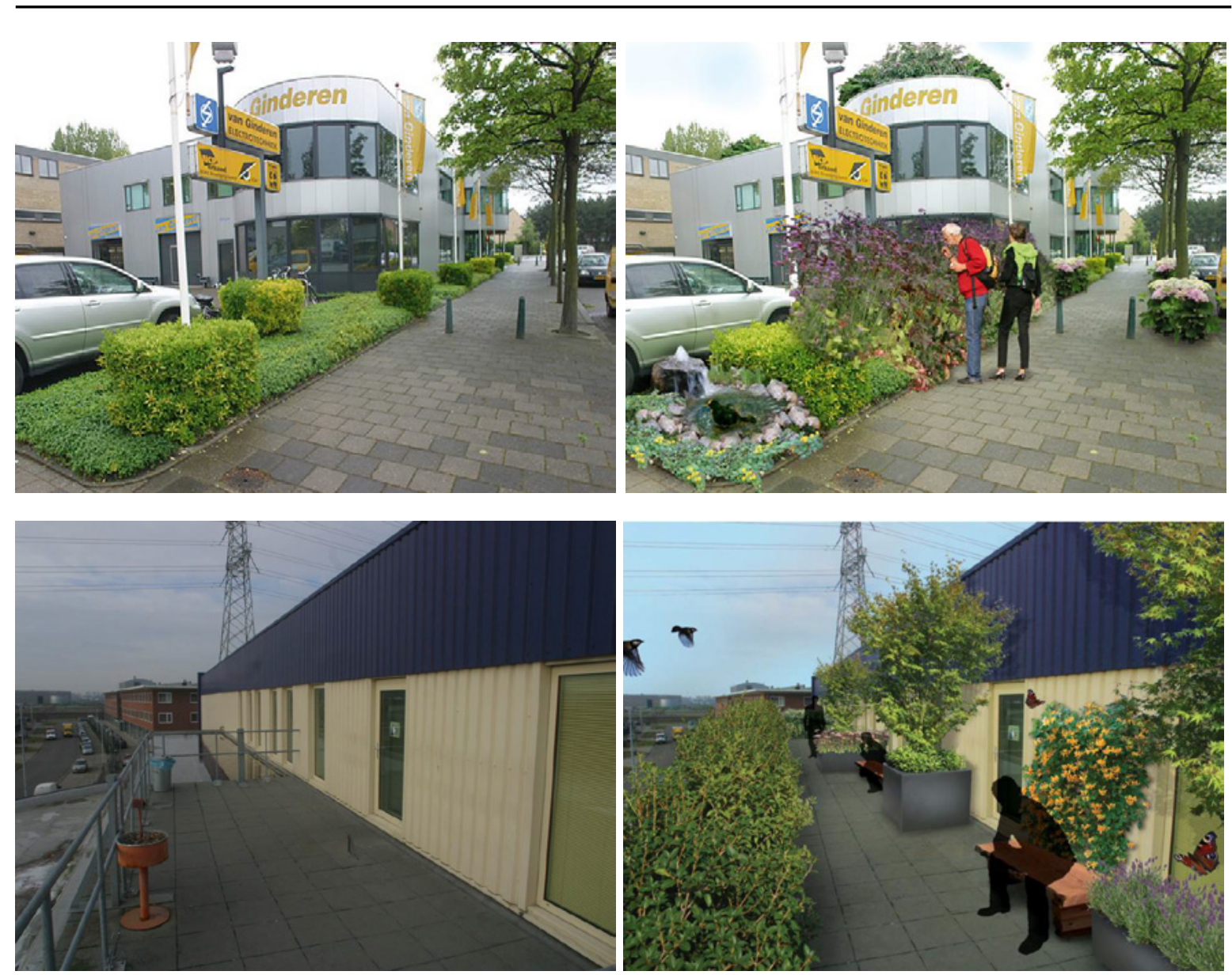

Op en rond bedrijven zijn vele mogelijkheden voor bij-vriendelijke inrichting en beheer (Bron: Foto's en bewerkingen: R. Snep).

Inspiratie:

Maak een looproute met de grasmaaier door het bloemrijke grasland: dit nodigt mensen uit om het grasland van dichtbij te beleven.

Plaats een informatiebord over wilde bijen, waardoor wandelaars het terrein met andere ogen zullen gaan bekijken.

Betrek een imker, verkoop honing/honing als relatiegeschenk (alleen als u ook honingbijen wilt).

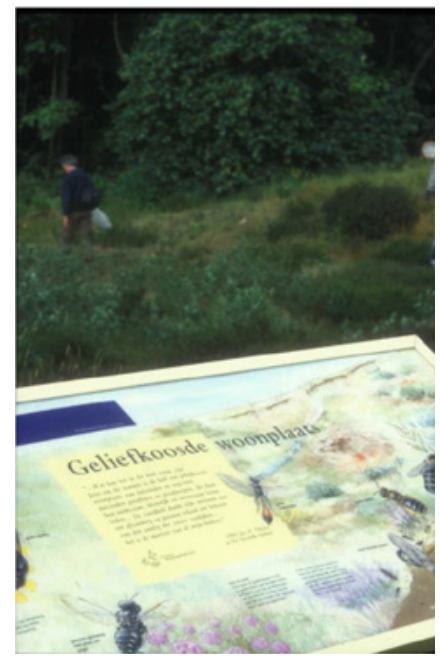

(Foto: M. Reemer). 


\subsection{Gemeentelijk groen}

Openbaar groen biedt het voordeel van grote oppervlakten, vaak in een goed verbonden groenstructuur door de stad en met verbinding naar het buitengebied. De groeninrichting is vaak weinig gevarieerd, met grote eenheden (gazon, uitheemse heesters, bosplantsoen) die vaak relatief weinig voedsel opleveren voor bestuivers. Mogelijkheden om de waarde van openbaar groen voor bijen, hommels en zweefvliegen te vergroten zodat ze als Bed \& Breakfast-gebied of verbindingszone met stapstenen kunnen fungeren in het bijennetwerk:

- Werk kleinschalig: meer afwisseling in hoogte en dichtheid van de vegetatie en meer bodemreliëf betekent mogelijkheden voor meer soorten.

- Vorm gazons en grasbermen om naar bloemrijk hooiland.

- Vorm heestervakken met uitheemse struiken om naar heesters of planten die voedsel bieden.

- Laat bomen en struiken in bloei komen. Soms worden meidoornhagen bijvoorbeeld al voor de bloei gesnoeid. Dan komen er dat jaar geen bloemen meer aan.

- Zorg hier en daar voor een paar vierkante meter open, droge grond in het zonbeschenen deel van het groen.

- Gebruik geen gif voor onkruidbeheer en tegen ziektes en plagen!

- Werk met inheemse bomen, struiken en kruiden. Deze bieden bijen voedsel- en nestgelegenheid.

- Zorg voor een mix van vroeg- en laatbloeiende soorten. Er is dan voor bijen en andere insecten gedurende het grootste deel van het jaar voedsel te vinden. Vroege bloeiers zijn diverse wilgensoorten en sleedoorn (zie boven), gele kornoelje en Spaanse aak. In het voorjaar en de vroege zomer bloeien meidoorn, zoete kers, linde en fruitbomen. Late bloeiers zijn braam, vuilboom en klimop. Stem de beplantingskeuze altijd af met het bodemtype en lokale (grond)waterstand. Dit is in hoge mate bepalend voor het 'aanslaan' van de beplanting.

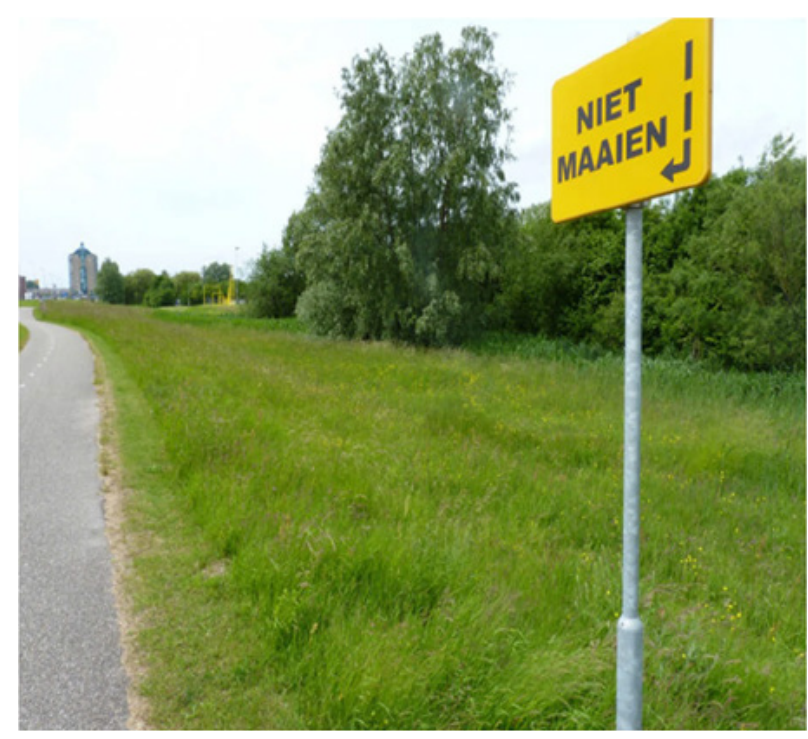

(Foto: M. Reemer).

\section{Inspiratie:}

Maak een looproute met de grasmaaier door het bloemrijke grasland: dit nodigt mensen uit om het grasland van dichtbij te beleven.

Plaats een informatiebord over wilde bijen, waardoor wandelaars het terrein met andere ogen zullen bekijken.

Zoek contact met scholen voor bouw en onderhoud van bijenhotels. 


\subsection{Oevers en bermen}

Overs en bermen bieden goede mogelijkheden voor bijen en andere bestuivers, vanwege de begroeiing (grazige vegetatie) en de vorm (linear: prima corridors). Door aanpassing van inrichting en beheer kunnen bermen en oevers het tussenliggende landschap bij-vriendelijker maken, Bed \& Breakfast-gebieden met elkaar verbinden en in gevallen waar flinke aaneengesloten oppervlakten bestaan, zelfs een Bed \& Breakfast-gebied vormen.

\section{Oevers:}

- Laat oevers niet te veel verruigen en maai ze ook niet in hun geheel. Overblijvend riet is nestgelegenheid voor bijen.

- Zet oevers deels af tegen vertrapping van de oevervegetatie door vee.

\section{Inrichting van bermen:}

- Zorg voor dood hout in de berm. Dood hout heeft een belangrijke functie voor insecten. Vanuit het oogpunt van verkeersveiligheid kan het noodzakelijk zijn om dode takken en toppen uit bomen langs wegen te verwijderen. Laat waar mogelijk een deel van de dode stam staan en leg snoeihout in de beplanting. Daar is het geschikt als leefgebied voor insecten en biedt het broedgelegenheid voor vogels.

- Kies voor een zandige afwerking van de berm bij aanleg van nieuwe wegen of herprofilering van bestaande wegen. Hiermee ontstaan goede kansen voor het vestigen van een bloemrijke vegetatie. Ook kan ook een inheems bloemenmengsel worden gezaaid, zodat de gewenste vegetatie zich sneller kan ontwikkelen.

- Kies bij aanplant van bomen voor soorten die bijdragen aan de voedselvoorziening van bijen en zweefvliegen (bijvoorbeeld linde- of wilgensoorten).

- Creëer extra nestgelegenheid voor bijen door zandige open plekken te maken, geschikt voor bijen die hun nest in de bodem maken of door het plaatsen van bijenhotels.

\section{Beheer van bermen en oevers:}

- Verschraal wegbermen, omdat dit leidt tot een snellere ontwikkeling van bloemrijke vegetaties. Dit kan worden bereikt door een beheer van maaien en afvoeren en door hooilandbeheer (zie hieronder: 'beheersystemen').

- Arme zandbodems - zoals die aanwezig kunnen zijn in wegbermen - kunnen één keer per jaar worden gemaaid, op voedselrijkere bodems is jaarlijks twee keer maaien en afvoeren nodig. Door vaker te maaien, verschraalt de bodem langzaam, omdat (rozetvormende) kruiden worden bevoordeeld ten opzichte van de grassen (zie Figuur 10).

- Laat vegetatie zich ontwikkelen waar het kan. Bij bermen dient rekening gehouden te worden met de verkeersveiligheid. In de eerste meter direct langs de weg, in bochten en bij kruisingen dient er goed zicht te zijn. In andere zones mag de vegetatie ruiger en hoger zijn, en kan ze een functie hebben voor overwinterende insecten.

- Maai pas nadat de meeste bloemen zijn uitgebloeid (zie kader).

- Let bij maaibeheer op de punten genoemd in 4.2.

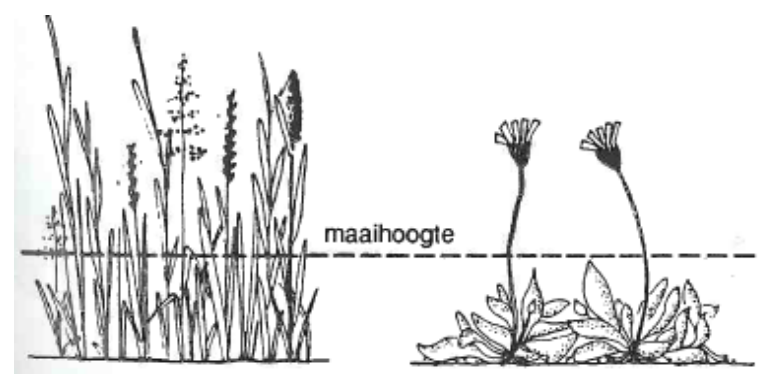

Figuur 10 Door maaien worden kruiden bevorderd boven grassen (Spijker et al., 1995). 


\section{Beheersystemen:}

- De natuurvriendelijkste methode is het hooien van de bermen en oevers. Hier blijft het maaisel enkele dagen in de berm liggen, wordt het gekeerd en op wiersen gelegd en daarna in rollen of pakjes verwerkt. Als het hooi van goede kwaliteit is (zonder afval of ongewenste planten), kan het door boeren worden gebruikt als ruwvoer.

- Richt het hooilandbeheer op de zone achter de eerste $3 \mathrm{~m}$ langs de weg. Het hooi van de strook direct langs de weg is van slechtere kwaliteit door depositie van uitlaatgassen en verzilting door strooizout. Bij gemeentelijke wegen leert de ervaring van gemeente Alphen aan den Rijn dat dit meevalt.

- Met de maai-zuigcombinatie wordt het maaisel geklepeld en direct opgezogen. Voordeel van dit systeem is dat de voedingsstoffen in het maaisel direct worden weggenomen en geen gelegenheid krijgen uit te spoelen naar de bodem. Nadeel is dat veel zaden en kleine dieren mee worden opgezogen.

- Een alternatief is gewoon maaien en het maaisel meestal direct na het maaien in rollen te persen en te voorzien van plastic folie.

- Maai vanaf de weg indien mogelijk. Door gebruik van maaigereedschap aan flexibele arm en vanaf de weg wordt de berm niet belast door het werktuig. Dit is gunstig voor het behoud van het bodemleven, ondergrondse nesten van bijen en andere insecten worden gespaard. Deze manier van maaien is met name toepasbaar bij smalle bermen en op niet te drukke wegen.

- Gebruik van speciale lagedrukbanden wanneer (bij brede bermen) gewerkt moet worden met een balenpers en de berm wordt bereden door de maai- en verzamelapparatuur. Dit vermindert de negatieve effecten op het bodemleven.

\section{Kosten natuurvriendelijker maaibeheer}

Het maaien en afvoeren van maaisel is op korte termijn wat duurder dan het klepelen van de bermen en het achterlaten van het maaisel op de plaats van vrijkomen. In dit laatste geval zal de berm echter sneller ophogen, waardoor de berm op een gegeven moment het zijdelings van de weg afstromende water niet meer goed kan opvangen. In dat geval moet de berm worden verlaagd. Dit is een kostbare maatregel die het voordeel van de lagere kosten weer voor een belangrijk deel tenietdoet.

Maaisel werd tot voor kort beschouwd als groenafval, maar wordt tegenwoordig steeds vaker toegepast als grondstof, bijvoorbeeld bij vergistingsinstallaties, bioraffinage en de productie van graskarton.

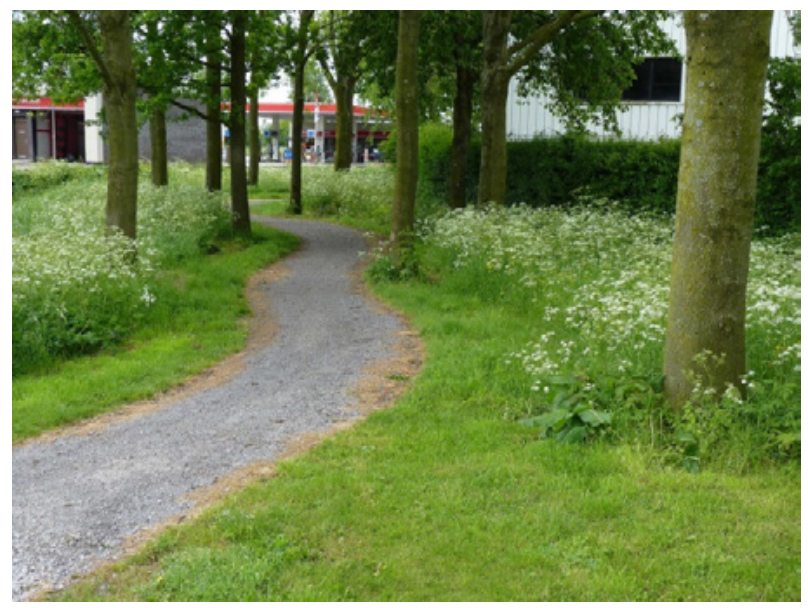

Laat vegetatie zich ontwikkelen waar het kan (Foto: M. Reemer). 


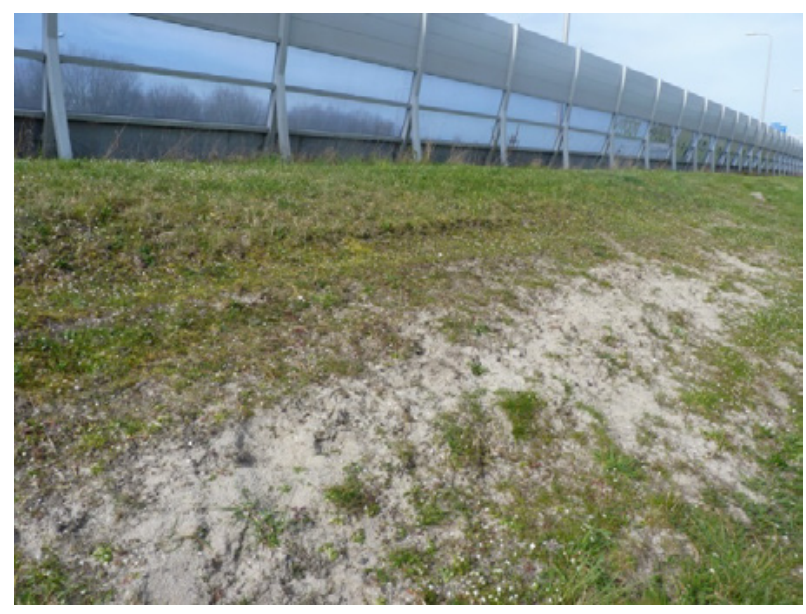

Taluds langs snelwegen kunnen erg geschikt zijn voor nestelgelegenheid voor bijen en zweefvliegen, zeker als ze op het zuiden georiënteerd zijn (Foto: M. Reemer).

\section{Inspiratie:}

Help de bodem in de berm schraal te houden door een verhoogde band langs de weg aan te leggen en regenwater van het wegdek af te voeren.

Leg een vlonderpad aan door de moerasvegetatie, zodat mensen de moerasplanten en -dieren van dichtbij kunnen zien.

Plaats een informatiebord over wilde bijen, waardoor wandelaars het terrein met andere ogen zullen gaan bekijken.

Gebruik holle stengels van afgemaaid riet voor bijenhotels. Bijvoorbeeld de stengels van Japanse duizendknoop (een exotische plant die vaak dominant optreedt en daarom als ongewenst wordt beschouwd) kunnen hier prima voor worden gebruikt.

\section{Borgen van bij-vriendelijk maaibeheer in Leiderdorp}

Voor een effectief, bij-vriendelijk maaibeheer is het niet alleen van belang om de juiste doelen te stellen, maar ook om goede en duidelijke afspraken te maken over de uitvoering van de benodigde maatregelen.

\section{Doelen vaststellen...}

Leiderdorp heeft voor de meeste bermen gekozen voor twee keer per jaar maaien. Op sommige plekken (kruispunten, zichthoeken) wordt vaker gemaaid in verband met de verkeersveiligheid. Op sommige stroken, bijvoorbeeld langs een bosplantsoen, wordt één keer per jaar gemaaid in het najaar.

Momenteel is de gemeente Leiderdorp aan het kijken of deze ook eens in de twee jaar kunnen worden gemaaid. Dit om betere overlevingskansen te bieden voor insecten die de winter in de hogere vegetatie overleven.

Een belangrijke doelstelling is om de eerste maaironde pas uit te voeren nadat de meeste bloemen zijn uitgebloeid en zaad hebben gezet.

\section{...en een goed uitvoering borgen!}

Om goede afspraken met de aannemer te kunnen maken, heeft Leiderdorp voor het tijdstip van maaien een indicatorsoort gekozen: de Margriet en in sommige gevallen Beemdooievaarsbek. Zodra de hoofdbloem van deze soort op een vooraf afgesproken berm zaad heeft gezet, kan de eerste maaironde daar van start gaan. De maaimachine gaat daarna in jaarlijks dezelfde volgorde de overige bermen maaien. Hierdoor wordt er gezorgd voor een jaarlijks gelijk beheer dat afgestemd is op het karakter van het groeiseizoen.

Leiderdorp heeft de afspraken vastgelegd in een frequentiebestek. De start van het maaien (direct nadat de hoofdbloem van de Margriet zaad heeft gezet), wordt gezamenlijk vastgesteld door aannemer en toezichthouder van de gemeente. Ook zijn er afspraken gemaakt over de maaihoogte (minimaal $5 \mathrm{~cm}$ ), de maaimethode (schotelmaaier) en het enkele dagen laten liggen van het maaisel voor het opnemen. Voor dit laatste geldt een uitzondering voor een enkele drukke weg. Daar wordt met een maai/zuigcombinatie gewerkt.

De gemeente Leiderdorp eist in het bestek dat de uitvoerders op de maaimachine beschikken over kennis van ecologisch beheer. Dit helpt voor een goede uitvoering van de werkzaamheden en is bovendien noodzakelijk om beschermde soorten in het kader van de Flora- en Faunawet te kunnen herkennen. Leiderdorp werkt hierbij met een gedragscode. 


\subsection{Agrarisch gebied}

Mogelijkheden om het agrarisch gebied bij-vriendelijker te maken en het landschap tussen Bed \& Breakfast beter met elkaar te verbinden, zullen zich op bedrijven vooral kunnen richten op de perceelranden:

- Zaai randen van weilanden, akkers en sloten in met bloemrijk mengsel (voedselplanten).

- Maai of hooi niet alle randen van weilanden, akkers en sloten binnen een korte periode, maar faseer in ruimte en tijd.

- Maai perceelranden minder frequent, zodat klavers en andere voedselplanten voldoende aanwezig zijn/langer in bloei kunnen staan. Laat bij maaien altijd een deel van de vegetatie staan (20\%).

- Creëer geleidelijke overgangen tussen weilanden en sloten.

- Laat 'rommelige' plekjes ontstaan, met bijvoorbeeld een braamstruweel, een oude boomstam of een zandheuveltje.

In een Verbindend Landschap moet ook ruimte zijn voor stapstenen, waar bijen tijdelijk kunnen foerageren en nestelen en eventueel een kleine populatie kunnen opbouwen. In een stapsteen kunnen zich her en der struiken of bomen bevinden, maar deze kan ook alleen uit droog of nat grasland bestaan.

\section{Inspiratie:}

Erven van boerderijen bieden vaak goede mogelijkheden voor bij-vriendelijke inrichting, bijvoorbeeld oude muurtjes, overhoekjes, beplanting, rieten daken en tuin. 


\section{Meer weten?}

\section{Bijlage bij dit rapport:}

Rooij, S. van, A. de Groot, W. Ozinga, M. Reemer \& A. Stip, 2020. Bijlagerapport 'Ecoprofielen voor het plannen van een regionaal netwerk voor bestuivende insecten in Laagveen/Zeeklei- en Duinlandschap'.

Te downloaden van www.groenecirkels.nl).

\section{Helpdesk Bijen}

De provincie Zuid-Holland heeft een helpdesk beschikbaar gemaakt die initiatiefnemers die een bijdrage willen leveren aan het regionale bijennetwerk verder op weg kan helpen. U kunt uw vragen over uw specifieke gebied stellen aan de provincie (mu.wiersema@pzh.nl). Bij honorering van uw vraag zetten Alterra en het EIS Kenniscentrum Insecten en andere ongewervelden hun expertkennis in voor de beantwoording daarvan.

Een overzicht van de gestelde vragen en het antwoord daarop van de experts wordt beschikbaar gemaakt op de website van Groene Cirkels (www. groenecirkels.nl).

\section{Bosrandbeheer voor vlinders en andere ongewervelden (Kars Veling e.a.)}

KNNV Uitgeverij, 2004.

Praktische handleiding voor bosrandbeheer gericht op 'kleine biodiversiteit'.

\section{Plantenvademecum voor tuin, park en landschap (Arie Koster)}

Fontaine Uitgevers, 2007.

Een uitgebreid overzicht van planten met aandacht voor hun waarde voor bijen. Niet alleen wilde planten, maar ook tuin- en plantsoenplanten komen aan bod. Met behulp van informatie over de eisen die de planten aan hun omgeving stellen, kan bepaald worden welke planten zich in een bepaald terrein thuis voelen.

Groenwerk: praktijkboek voor bos, natuur en stedelijk groen (Spijker, J.H. (red.), C.M. Niemeijer (red.) en G.J. Tjooitink (eindred., 1995).

Misset uitgeverij bv, Doetinchem. 


\section{Woordenlijst}

Bed \& Breakfast-gebied: Bouwsteen van het Bijennetwerk. Een leefgebied waar veel soorten bestuivende insecten voldoende nestgelegenheid en gedurende het hele jaar voedsel vinden, en waar ook op lange termijn een gevarieerde bevolking van bestuivende insecten kan voorkomen.

Bouwstenen:

Onderdelen waaruit een Bijennetwerk is of kan worden opgebouwd.

Bijennetwerk:

Netwerk van leefgebieden voor bestuivende insecten in het landschap. De bouwstenen vormen onderdelen van dit netwerk van leefgebieden.

Bij-tankstation: Bouwsteen van het Bijennetwerk. Kleine bij-vriendelijke plekken, zoals tuinen en balkons, die geïsoleerd van het netwerk zijn gelegen. Deze helpen bijen, vlinders en zweefvliegen om afstanden door 'bloemenarm' landschap te overbruggen.

Ecoprofiel:

Een gemeenschap van bijen, zweefvliegen en vlindersoorten die ongeveer dezelfde eisen aan het landschap stelt om duurzaam te kunnen voorkomen.

Habitat:

Leefgebied voor een bepaalde soort. Sommige soorten hebben verschillende soorten habitat nodig om hun levenscyclus te voltooien, bijvoorbeeld voedselhabitat en habitat waar een soort zijn nestgelegenheid vindt.

Verbindend Landschap:

Bouwsteen van het Bijennetwerk. Habitatrijk landschap tussen Bed \& Breakfast-gebieden dat soorten in staat te stelt relatief makkelijk van het ene gebied het andere te bereiken. Na extreme weersomstandigheden, ziekten of met opschuivende klimaatzones kunnen soorten sneller Bed \& Breakfast-gebieden (her)bevolken. Dit draagt bij aan de soortenrijkdom in de Bed \& Breakfast-gebieden en aan het bijennetwerk in zijn geheel. 
Wageningen Environmental Research Postbus 47

6700 AA Wageningen

T 0317480700

www.wur.nl/environmental-research

Wageningen Environmental Research

Rapport 2999

ISSN 1566-7197
De missie van Wageningen University \& Research is 'To explore the potential of nature to improve the quality of life'. Binnen Wageningen University \& Research bundelen Wageningen University en gespecialiseerde onderzoeksinstituten van Stichting Wageningen Research hun krachten om bij te dragen aan de oplossing van belangrijke vragen in het domein van gezonde voeding en leefomgeving. Met ongeveer 30 vestigingen, 5.000 medewerkers en 12.000 studenten behoort Wageningen University \& Research wereldwijd tot de aansprekende kennisinstellingen binnen haar domein. De integrale benadering van de vraagstukken en de samenwerking tussen verschillende disciplines vormen het hart van de unieke Wageningen aanpak. 


\section{‘HEINEKEN}

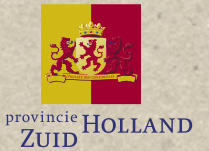

WAGENINGEN UNIVERSITY \& R

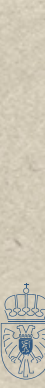

Rijnland

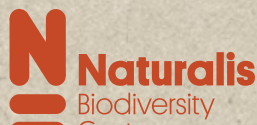

Biodiversity

Center
HEINEKEN Nederland

contactpersoon Jan Kempers

Burgemeester Smeetsweg 1

$2382 \mathrm{PH}$ Zoeterwoude

jan.kempers@heineken.com

telefoon +31 715457611

www.heinekennederland.nl

\section{Provincie Zuid-Holland}

contactpersoon Linneke van Heemskerck Duker

Zuid-Hollandplein 1

2509 LP Den Haag

I.van.heemskerckduker@pzh.nl

telefoon +31 704418466

www.zuid-holland.nl

\section{Wageningen Environmental Research}

contactpersoon Eveliene Steingröver

Droevendaalsesteeg 3

6708 PB Wageningen

eveliene.steingrover@wur.nl

telefoon +31317485874

www.wur.nl/environmental-research

\section{Hoogheemraadschap van Rijnland}

contactpersoon Timo van Tilburg

Archimedesweg 1

2333 CM Leiden

timo.tilburg@rijnland.net

telefoon +31 621689939

www.rijnland.net

\section{Naturalis Biodiversity Center}

Vondellaan 55

2332 AA Leiden

communicatie@naturalis.nl

telefoon +31 713063665

www.naturalis.nl 
Dit rapport hoort bij het Groene Cirkels thema Leefomgeving

\section{Een Bij-zonder kleurrijk landschap in Land van Wijk en Wouden, Leidse Ommelanden en Duin- en Bollenstreek}

Handreiking $\mathbf{3 . 0}$ voor inrichting en beheer van groene infrastructuur voor bestuivende insecten

Sabine van Rooij (redactie), bijdragen van Anouk Cormont, Willemien Geertsema,

Arjen de Groot, Martijn Haag, Paul Opdam, Menno Reemer, Robbert Snep, Joop Spijker, Eveliene Steingröver, Anthonie Stip en Wim Ozinga.

Dit onderzoek is uitgevoerd door Wageningen Environmental Research, in opdracht van en gefinancierd door het programma Groene Cirkels Bijenlandschap, onderdeel van Groene Cirkels, de samenwerking tussen HEINEKEN, provincie Zuid-Holland, Wageningen Environmental Research, Hoogheemraadschap van Rijnland en Naturalis Biodiversity Center.

WENR-rapport 2999

Groene Cirkels rapport 11

ISSN 1566-7197

maart 2020

Voor meer informatie: Sabine van Rooij, sabine.vanrooij@wur.nl 